\title{
Reducing fisheries impacts on the seafloor: a bio-economic evaluation of policy strategies for improving sustainability in the Baltic Sea
}

Bastardie, Francois; Danto, Jules; Rufener, Marie-Christine; van Denderen, Pieter Daniël; Eigaard, Ole R.; Dinesen, Grete E.; Nielsen, J. Rasmus

\section{Published in:}

Fisheries Research

Link to article, DOI:

10.1016/j.fishres.2020.105681

Publication date:

2020

Document Version

Peer reviewed version

Link back to DTU Orbit

Citation (APA):

Bastardie, F., Danto, J., Rufener, M-C., van Denderen, P. D., Eigaard, O. R., Dinesen, G. E., \& Nielsen, J. R. (2020). Reducing fisheries impacts on the seafloor: a bio-economic evaluation of policy strategies for improving sustainability in the Baltic Sea. Fisheries Research, 230, [105681]. https://doi.org/10.1016/j.fishres.2020.105681

\section{General rights}

Copyright and moral rights for the publications made accessible in the public portal are retained by the authors and/or other copyright owners and it is a condition of accessing publications that users recognise and abide by the legal requirements associated with these rights.

- Users may download and print one copy of any publication from the public portal for the purpose of private study or research.

- You may not further distribute the material or use it for any profit-making activity or commercial gain

- You may freely distribute the URL identifying the publication in the public portal 


\title{
Accepted in Fisheries Research
}

\section{https://doi.org/10.1016/j.fishres.2020.105681}

copy available at: https://authors.elsevier.com/a/1bMgabiU1p3IV

\section{Reducing fisheries impacts on the seafloor: a bio-economic evaluation of policy strategies for improving sustainability in the Baltic Sea}

Francois Bastardie, Jules Danto, Marie-Christine Rufener, Daniel van Denderen, Ole R. Eigaard, Grete E. Dinesen, J. Rasmus Nielsen

Corresponding author: fba@aqua.dtu.dk. Technical University of Denmark, National Institute of Aquatic Resources (DTU Aqua), Kemitorvet, 2800 Kgs. Lyngby, Denmark

(C) 2020. This manuscript version is made available under the CC-BY-NC-ND 4.0 license http://creativecommons.org/licenses/by-nc-nd/4.0/

\section{Highlights}

- Restricting fishing areas does not equate to reducing ecosystem impacts on benthic habitats

- Displacing fishing efforts can offset the gains in partial habitat protection

- The benthic status in Kattegat improves more than the benthic status in central Baltic when using spatial management measures

- Largest improvement is achieved by protecting long-lived communities from high-impact fisheries

- Healthy fish stocks reduce the risk to both the seafloor integrity and fishery economics

\begin{abstract}
Under the European Union's Marine Strategy Framework Directive (MSFD) and Common Fisheries Policy (CFP), management organisations are directed to evaluate measures for reducing the footprint of fishing on the seafloor. We applied a spatial modelling platform to evaluate the effects of spatial fishery management measures on the Baltic Sea. The evaluation includes restricting areas for fishing with the dual goal of reducing the impact on benthic habitats and minimising negative effects on fishery catch and profit. To redistribute the fishing effort realistically, the model simulates individualvessel agents and behavioural rules. The model integrates benthic community dynamics by combining gear-specific depletion rates from fishing agents with habitat-specific trait-based recovery rates for the benthic communities. Our simulations showed that closing areas in the central Baltic Sea and condensing the fishing efforts into core fishing areas did not improve the relative benthic status (RBS). In addition, the fisheries were adversely affected by reduced fishing opportunities, further impacting their economic performance. The potential for improving the overall RBS with spatial management is dubious in the central Baltic, given that the area is dominated by relatively short-lived and rapidly recovering benthic species. By contrast, the Kattegat showed a substantial improvement in the RBS, as determined by measures combining the protection of long-lived benthic communities with the mitigation of high-impact fisheries. Our results and investigations provide different bioeconomic scenarios on benthos and fisheries dynamics resulting from specific management measures.
\end{abstract}


The developed knowledge base and modelling tool is expected to assist policymakers in identifying the most appropriate measures to achieve both a Good Environmental Status (GES) of the seafloor according to the MSFD and to maintain sustainable fisheries and stocks according to the CFP.

\section{Keywords}

Baltic Sea, benthic habitats, cost-effectiveness, ecosystem-based fisheries management (EAFM) evaluation of marine and fishery policy strategies, fisheries economics, fishing impacts, spatial footprint

\section{Introduction}

The ecosystem approach to fisheries management (EAFM) aims to protect the seas and their resources using specific environmental policy instruments. These instruments pose new, possibly conflicting challenges because they must be aligned with the fisheries policy itself to develop and maintain a sustainable use of marine resources (Garcia et al. 2003, Long et al. 2015, Trochta et al., 2018). Nevertheless, in Europe and beyond, fisheries management measures should now be developed in an integrated manner so that they contribute jointly to (or are not incompatible with) mitigating the effects of fishing on ecosystem structure and functioning. Hence, the EU Marine Strategy Framework Directive (MSFD; EC 2017) explicitly refers to the EU Common Fishery Policy (CFP; EC 2013). The given policy instruments should mitigate or minimise fishing effects not only on fishery resources but also other components of the marine ecosystems (marine habitat and non-target species). In addition, fishing should ensure a viable outcome for fishers, secure food provisions for society and respond to fish market demands in Europe and globally.

One of the primary fishing impacts on the marine ecosystems to be considered in an EAFM is the biophysical effects of the direct and indirect pressures exerted by fishing operations on the seafloor, primarily from mobile bottom-contacting gears (e.g., Eigaard et al. 2016, Kaiser et al. 2016, Hiddink et al. 2017 and 2019, Pitcher et al. 2017). Another notable impact is the incidental by-catch of birds and marine mammals resulting from fishing operations when using various passive gears (e.g., KindtLarsen et al. 2016; Glemarec et al. 2020). To address policy needs relating to integrating the fishing impacts of the spatial footprint from bottom-contacting fishing gears on the seafloor, we face a fourfold issue: i) identify the seafloor impact and the management options to mitigate seafloor impact; ii) identify the effects of spatial measures regulating fishing practices on the incidental damage and bycatch of marine birds and mammals; iii) determine how the fishery exploitation of target species is affected by these mitigation measures and how they risk incidental catches of birds and marine mammals, given the technical interactions between fisheries; and iv) identify how fishery economics are affected by potential mitigation measures.

The Baltic Sea is a semi-closed sea area that endures multiple anthropogenic pressures and effects, such as eutrophication, marine litter, the introduction of invasive species, and seabed disturbance and loss (ICES 2018). This study evaluates different management scenarios to identify appropriate measures for achieving a good environmental status (GES) and preserving the seafloor integrity over the long term, as stipulated by EU policy (EC 2017) and stressed in the Baltic Sea Action Plan (HELCOM 2018). Among the potential mitigation tools, such as reduced fish quotas or the development of innovative gears, spatial restrictions of fishing efforts are frequently proposed (EC 2013b, Thrush et al. 2016, McConnaughey et al. 2020). To explore the utility and robustness of these measures, we have defined and tested a suite of spatially based mitigation scenarios. We compared the bio-economic effects along a gradient of restrictions relating to fishing and area closures in 
different locations, seafloor habitat types, and exclusive economic zones (EEZ). The impact of these spatial measures was quantified by inferring pressure-state relationships with the resulting change in the relative benthic status (RBS) of the seafloor (ICES 2019a, Rijnsdorp et al. 2020) as well as the difference in the economic performance of the different fisheries when attempting to improve the state of the seafloor in the Baltic Sea.

Analyses of spatial fishing effort distributions show that effort is typically concentrated within specific areas (e.g., Rijnsdorp et al. 1998, Dinmore et al. 2003, Bastardie et al. 2010, Jennings et al. 2012, Eigaard et al. 2016) and that the first trawl pass is likely the most detrimental to the seafloor (e.g., Pitcher et al. 2017). For that reason, our scenarios are focused on the contraction of effort in the current most frequently visited fishing areas (defined here as "core fishing grounds"). Redirecting fishing to the core fishing grounds will put additional pressure on areas that are already heavily impacted and that contribute the most to the fishery economy. This displacement may result in some benefits for the protected areas along with minimising the apparent cost of the protection to fishing, provided that the core fishing grounds would still be fished (McConnaughey et al. 2020) However, this change might come with possible harmful consequences in the areas that are still open (Dinmore et al., 2003). For example, adverse effects on exploited living marine resources are to be expected if fleets are targeting species that are strongly associated with sensitive habitats (Poos \& Rijnsdorp, 2007). In this study, we use a spatially explicit model to simulate the cost efficiency and the possible underlying trade-off in spatial fisheries management. This model evaluates different levels and patterns in displacing a baseline fishing effort, with the intention of safeguarding the seafloor integrity and improving its overall state, also beyond the protected areas. We therefore apply a spatial restriction to the space available for fishing by cutting grid cells where historical fishing efforts have been observed. We start the cut where the fishing would not be allowed anymore, from the low-effort, low-value peripheral cells, and we define this cut as a "peripheral fishing effort cut". However, it corresponds to a spatial restriction only, not an effort reduction as such. We test whether these spatial measures might offset the benefit obtained by releasing the pressure on conservation areas.

A unique utility of our approach is the estimation of displacement patterns in fishing pressure in reaction to management measures (spatial scenarios). Following area closures, fishing effort will generally be re-allocated to the remaining open areas that increase or maintain economic efficiency for fisheries. With the identification and model integration of behavioural rules, it is possible to predict the effects on CFP and MSFD-related estimates and indicators. A previous evaluation tested the performance of alternative CFP-related scenarios, such as fishing for the maximum sustainable yield, or MSY, to ensure economically viable and sustainable Baltic Sea fisheries (Bastardie et al. 2015). In the present study, in addition to the CFP scenarios, we explore MSFD-related scenarios for management measures intended to close the gap towards GES for benthic habitats that are adversely affected by fisheries that use mobile bottom-contacting gears. Performance tests are designed to track changes in the MSFD targets, among which "Biological diversity is maintained (habitats and species)", "Populations of all commercially exploited fish and shellfish are within safe biological limits", and "Seafloor integrity is at a level that ensures that the structure and functions of the ecosystems are safeguarded". Measuring performance refers to detailing the costs/benefits and tradeoffs for fisheries economics, and it is of paramount importance for managers to base their decisions on this information. To address the MSFD seafloor integrity target, the spatial extent and distribution of physical loss and disturbance pressures for each MSFD broad habitat type, within each ecoregion and subdivision, must be assessed. Our work helps advise on assessments of MSFD management measures, in addition to the CFP management measures, to ensure that the seafloor integrity is at a level that ensures the structure and functioning of the benthic ecosystems and habitats are not adversely affected (EC, 2017). 
Our study first examines whether the magnitude of fishery impacts on the benthic habitat is posing a challenge to fishery management. Second, we examine whether the fishing impact on benthic physical habitats and benthic invertebrate communities can be reduced by limiting the spatial extent of the pressure according to different scenarios based on where the fishing takes place. Third, our study examines whether the exploitation of the harvested population remains sustainable, and then finally, whether the most likely minimisation of the effect of restricting the fisheries on the fisheries and fisheries economics will begin when initiating the effort displacement from the periphery of the historical fishing grounds. The present evaluation builds on an assessment methodology, in which the benthic impact from bottom-trawling is predicted at the community level using a population dynamic growth model (Pitcher et al. 2017, Mazor et al. 2017). The model includes a pressure-specific depletion rate (Hiddink et al. 2018) and assumes that the recovery rate of a benthic community depends on the longevity of the fauna (Hiddink et al. 2019). The assessment methodology has been implemented in the Baltic Sea (van Denderen et al. 2020). In this study, it was shown that most communities in the Baltic Sea consist of short-lived species $(<5$ years). By contrast, benthic communities in the high-saline Kattegat are dominated by long-lived species ( $>10$ years) and are predicted to be more vulnerable to bottom trawling. In this study, we integrate the benthic impact assessment methodology with a fleet dynamic modelling platform (DISPLACE; Bastardie et al. 2014) to inform managers about the options on how to most cost-effectively reduce the environmental impact of bottom fishing on seafloor habitats and their integrity.

\section{Methods}

We used the DISPLACE modelling platform (Bastardie et al. 2014, Supplementary materials SM1) as a comprehensive management strategy evaluation tool to assess how fish stocks, fisheries, and benthic habitats are affected by different spatial fishery management options. We therefore inform the modelling platform with existing data collected with the current monitoring systems (Table 1, Supplementary materials SM2) to benchmark the effectiveness of alternative management measures and spatial plans affecting fisheries in regards to reducing the pressure on various ecosystem components. We designed the framework such that other human-induced activities that are disturbing the seafloor could accumulate towards the overall benthic impact. Other pressures primarily concerned the resuspension of the sediment (e.g., Trimmer et al. 2005), i.e., the physical disturbance that is exerted by both fishing lanes and the contact of the fishing gear with the sea bottom. In brief, the core of DISPLACE is a spatial bio-economic model for simulating the movement of individual fishing vessel agents combined with an underlying spatial population dynamics model. In DISPLACE, individual agents optimise their decision-making on the fly depending on their given catch rates by zones and the expected cost to reach the zone and return to the harbour. Each vessel depletes the target stocks individually, which further depends on the gear type in use, and it has additional impacts on unwanted species (such as marine mammals and seabirds) with bycatch. The model accounts for real cases of individual footprints and uses the best available fisheries-related science delivered by ICES (such as Vessel Monitoring System data (VMS) coupled to logbook data, as in Bastardie et al. (2014), or by specific depletion effects from different gear types, as in Bastardie et al. 2017).

Within the present study, we extended and conditioned DISPLACE to encompass the benthos dynamics and applied the DISPLACE modelling platform to wide-scale international Baltic Sea fisheries. Because the Baltic fisheries that impact the seafloor are using bottom-contacting gear that covers and affects several benthic communities in the Baltic (Gogina et al. 2016), the present model 
addressed different benthos longevity groups (0-1 years, 1-3 years, 3-10 years and >10 years) and ICES subareas. The longevity groups should reflect the diversity of the impacted seafloor as a component of the overall assessment, and this assessment identifies the potential impact of the current and future pressures on the "good state" of benthic habitats (Rijnsdorp et al. 2016). We informed the new DISPLACE benthos model with a prediction of the benthic community longevity estimated from 1558 locations across the Baltic Sea on a $0.05^{\circ}$ x $0.05^{\circ}$ grid (van Denderen et al. 2020). We projected the benthos dynamics in response to fishing pressures using a population dynamic growth model as performed by Pitcher et al. (2017). We then quantified the depletion rate from bottom trawling fishing gear, as in Hiddink et al. (2017). We considered a recovery rate that depends on the predicted benthic community longevity as conducted by Hiddink et al. (2019). The dynamic population model estimates a relative benthic status (RBS), which is the biomass of the benthic community relative to the carrying capacity. In the context of evaluating the effect of fishing impacts on the seafloor, the fishing gear and fishing intensity and the area swept by the specific gear (swept area ratio or SAR as described in Eigaard et al. 2016) determine the benthic mortality. By contrast, benthos recovery occurs in between fishing events at rates specific to the longevity of each benthos group. The relationship between recovery $r$ and longevity is $r=5.31 /$ longevity, as given in Hiddink et al. (2019).

Table 1. Type of data collection and monitoring program data used to condition the DISPLACE Kattegat and Baltic Sea application

\begin{tabular}{|c|c|c|c|c|}
\hline Monitoring systems & Type of data & Model agents & Source & Legislation \\
\hline $\begin{array}{l}\text { Emodnet marine habitat } \\
\text { mapping }\end{array}$ & Marine habitats (EUNIS level 3) & Background maps & www.emodnet.eu & EU MSFD (EC 2017a) \\
\hline EU Fleet register & $\begin{array}{l}\text { Individual vessel physical } \\
\text { features }\end{array}$ & Fishing vessels & ec.europa.eu/fisheries/cfp/ & $\begin{array}{l}\text { EU CFP (Data Collection } \\
\text { Framework in EC 2017b) }\end{array}$ \\
\hline $\begin{array}{l}\text { EU STECF annual } \\
\text { economic report AER }\end{array}$ & $\begin{array}{l}\text { Catch rates per species, } \\
\text { Fisheries economics per fleet- } \\
\text { segment informing individual } \\
\text { vessel features }\end{array}$ & Fishing vessels & stecf.jrc.ec.europa.eu/ & $\begin{array}{l}\text { EU CFP (Data Collection } \\
\text { Framework in EC 2017b) }\end{array}$ \\
\hline $\begin{array}{l}\text { EU STECF Fisheries- } \\
\text { dependent information } \\
\text { (FDI) }\end{array}$ & $\begin{array}{l}\text { Volume of landings and effort per } \\
\text { fleet segment informing species } \\
\text { catch rates }\end{array}$ & Fishing vessels & stecf.jrc.ec.europa.eu/ & $\begin{array}{l}\text { EU CFP (Data Collection } \\
\text { Framework in EC 2017b) }\end{array}$ \\
\hline $\begin{array}{l}\text { ICES analytical stock } \\
\text { assessments }\end{array}$ & $\begin{array}{l}\text { Biological information on } \\
\text { harvested species (e.g., number- } \\
\text { at-age) }\end{array}$ & Harvested species & See in Annexe 1 & EU CFP (EC 2013) \\
\hline $\begin{array}{l}\text { ICES Spatial fisheries } \\
\text { data }\end{array}$ & $\begin{array}{l}\text { VMS logbook-coupled data and } \\
\text { fisheries data informing (fishing } \\
\text { effort distribution) }\end{array}$ & Fishing vessels & ICES WGSFD & EU CFP (EC 2013) \\
\hline HELCOM Shipping data & $\begin{array}{l}\text { AIS tracking data for vessel } \\
\text { density maps }\end{array}$ & $\begin{array}{l}\text { Commercial } \\
\text { shipping }\end{array}$ & www.maps.helcom.fi & EU MSFD (EC 2017a) \\
\hline Benthos sampling & Biomasses per taxon on station & $\begin{array}{l}\text { Benthic functional } \\
\text { groups }\end{array}$ & $\begin{array}{l}\text { Gogina et al. } 2016 \\
\text { van Denderen et al. } 2020 \\
\text { ICES WGFBIT }\end{array}$ & EU MSFD (EC. 2017a) \\
\hline Marine mammals & Density maps & Unwanted catches & Edrén et al 2010 & EU MSFD (EC 2017a) \\
\hline Birds & Presence/absence & Unwanted catches & eea.europa.eu & EU HD (EC 1992) \\
\hline
\end{tabular}




\section{Scenarios to mitigate the fishing impact on the seafloor}

All the scenarios (Table 2) are evaluated against the baseline, which corresponds to the business-asusual scenario describing the spatial fishing footprint and exploitation under conditions applied through the management plan in the Baltic Sea in 2016, the most recent year when we had available data. The baseline simulated individual fishing vessels larger than $12 \mathrm{~m}$ in length using mobile bottom-contacting gear and vessels larger than $10 \mathrm{~m}$ using entangling nets. We therefore also simulated netters even if the restriction only applies to bottom-contacting gear, since it is likely that the effect will propagate to the entire fishing fleet when technical and biological interactions can occur. The comparison of the baseline with different mitigation scenarios enables an evaluation of alternative management options. The baseline scenario includes biological reference points and the targets used in the current EU CFP-related FMSY and TACs fisheries management of the Baltic Sea. Management includes the 2016 monthly closure to fishing that was implemented to protect Baltic cod stocks. The Baltic multi-annual management plan of the European Union (EC 2016) and its 2018 revision enforce a seasonal closure for western Baltic cod from February 1 to March 31, and from July 1 to August 31 for eastern Baltic cod.

Table 2. Description of types of scenarios tested in the current Baltic Sea-wide DISPLACE application

\begin{tabular}{|c|c|c|}
\hline Type of scenarios & Description & Scenario naming \\
\hline $\begin{array}{l}\text { Spatially restricted areas on } \\
\text { the periphery of fishing } \\
\text { grounds, as applied per } \\
\text { Exclusive Economic Zone } \\
\text { (EEZ) }\end{array}$ & $\begin{array}{l}\text { No-take zone at the edge of the core fishing grounds along with an } \\
\text { increased percentage of fishing effort. These scenarios assume that a } \\
\text { displacement will occur, concentrating the effort in the remaining } \\
\text { open areas. No-take is no longer accessible for fishing in all vessels } \\
\text { with mobile bottom-contacting gears. }\end{array}$ & $\begin{array}{l}\text { [Bottom gears } x \% \text { cut }(\mathrm{EEZ})] \\
\text { with } x \text { along with } 5,10,15,20,25,30 \text {, } \\
\text { and } 50 \%\end{array}$ \\
\hline $\begin{array}{l}\text { Spatially restricted areas on } \\
\text { the periphery of fishing } \\
\text { grounds, as applied per type } \\
\text { of habitat (EUNIS EMODNet } \\
\text { habitat Level 6) }\end{array}$ & Same as above & $\begin{array}{l}{[\text { Bottom gears } x \% \text { cut }(\mathrm{HAB})]} \\
\text { with } \mathrm{x} \text { along } 5,10,15,20,25,30 \text {, and } 50 \%\end{array}$ \\
\hline $\begin{array}{l}\text { Spatially restricted areas in } \\
\text { the core of fishing grounds }\end{array}$ & $\begin{array}{l}\text { No-take zone at the core of fishing grounds along with an increased } \\
\text { percentage of fishing effort. These scenarios assume that an effort } \\
\text { displacement will occur towards remaining open areas. The no-take } \\
\text { zone is no longer accessible for fishing for all vessels with mobile } \\
\text { bottom-contacting gears }\end{array}$ & $\begin{array}{l}\text { [Bottom gears } x \% \text { cut on core }(\mathrm{EEZ})] \\
\text { with } \mathrm{x} \text { along with } 30, \text { and } 50 \%\end{array}$ \\
\hline Fewer trips & $\begin{array}{l}\text { Less overall effort deployed by affecting the total number of trips } \\
\text { deployed for each vessel using mobile bottom-contacting gears. }\end{array}$ & [10\% fewer trips] \\
\hline Restriction on nets & $\begin{array}{l}\text { The area designated for mitigation is no longer accessible for fishing } \\
\text { to all vessels using passive gears Here, we used the EU Habitat } \\
\text { Directive Natura } 2000 \text { sites designated in the Baltic Sea } \\
\text { (eea.europa.eu). These marine areas in the western Baltic and the } \\
\text { Kattegat were especially designed to prevent incidental catches of } \\
\text { marine birds. }\end{array}$ & [Restriction on nets] \\
\hline $\begin{array}{lcc}\text { Restriction on nets }+ \\
\text { Restriction on } \\
\text { Contacting Gear }\end{array}$ & Combine the scenarios described above. & $\begin{array}{l}\text { [Bottom gears } 30 \% \text { cut } \quad(\text { EEZ) }+ \\
\text { Restriction on nets] }\end{array}$ \\
\hline
\end{tabular}


The tested scenarios (Table 2) implement no-take areas for bottom-contact gears; for example, based on a displacement of the actual fishing effort from the least visited areas towards the most often visited areas. Because fishing effort is patchily distributed and typically concentrated in core areas (Eigaard et al., 2016), the effort in these scenarios assumes a reduction in the peripheral areas of the fishing grounds to concentrate the fishing effort in already more frequently fished areas (Fig. 1). It is therefore expected that it is the way for the catching sector to attain the same catch that will minimise the impact on the seafloor. This approach encompasses the fact that the highest impact on the benthic habitats and communities is observed the first time the seafloor is subject to fishing pressure, compared to repeated pressure at a given locality. The approach is intended to support the identification of a percentage of minimal areas subject to fishing restrictions that would achieve the management goals. Minimal areas indicate the benefits of reaching GES and the concurrent impact on fishery economics. Minimal areas should also capture benefits (or costs) in displacing the effort to the already more heavily impacted areas in an attempt to reach the same catch level. Re-allocation is estimated from the likelihood of re-allocation areas based on previously known fishing patterns on an individual vessel basis. We also tested the opposite scenarios, i.e., by reducing the fishing effort by starting the cut on core grounds where the highest baseline effort is applied.

In the evaluated spatial scenarios, the fishing effort displacement can be applied either per national exclusive economic zone (EEZ) separately or per type of MSFD broad habitat type (HAB). The rationale for applying the displacement per EEZ assumes that the policy is intended to be implemented in a non-coordinated manner and on a strictly national basis consistent with the MSFD setting. The habitat typology we use here follows the EUNIS level 3 classification (e.g., Eigaard et al.2016).

We addressed both knowledge and structural uncertainties by running stochastic simulations in a management evaluation framework by considering different management options. In our study, we accounted for i) the effects exerted by the structured application of fishing pressure that makes sense to fishing agents and ii) uncertainties in the recovery rate values of benthic fauna and communities (means and coefficients of variation obtained from Hiddink et al. (2018). Point (i) is relevant when considering spatial management measures such as area closures. Agent-based models, i.e., an individual fishing vessel-based models in our case, have an advantage over statistical models because they avoid proportionally redistributing the fishing effort over the remaining open areas (ICES 2019b). Point (ii) will require future refinement to incorporate uncertainties in the longevity classification. The scenarios are simulated for a five-year time horizon at an hourly time interval, with a total of 10 stochastic replicates for each one. For each scenario, we combine different output indicators into the graphics. The graphics concern the indicators of i) the fish population dynamics (spawning stock biomass SSB, the fishing mortality F); ii) the magnitude of incidental catches of birds and marine mammals (supplementary materials SM2); iii) the economic profitability of the vessels or fisheries (income from landings, operating costs, energy use efficiency, marginal contributions, and income inequality); and iv) the benthos dynamics of the total community (the relative benthos status RBS varying between 0 and 1 , with 0 being the entire depletion and 1 being a community at full carrying capacity) and per longevity group (describing the change in RBS for a subset of the community, where RBS varies between 0 and the proportion of the community within that specific longevity grouping). For each indicator, we compare the relative performance and the robustness against the outcomes of the baseline run situation, and we evaluate the positive/negative trend compared to the initial state. 


\section{Results}

\subsection{Fishing pressure-seafloor state response curves to spatial measures}

The simulated fishing pressure affected the seafloor and the simulated relative benthic status for shortlived (1-3 years) and more long-lived (3-10 years) benthic animals differently (Fig. 2). Although some benthos longevity groupings recover towards the benthos carrying capacity (i.e., for the shortlived benthic animal longevity group of 1-3 years in ICES SDs 24 and 25, and the more long-lived benthic animals in the 3-10 years longevity group in SD 26), others converge towards a stable equilibrium (communities in ICES SD 22 and area IIIa). The recovery was quicker for short-lived fauna, as expected, (Fig. 2, left) than for long-lived fauna (Fig. 2, right). In this context, the simulation shows a limited effect from changing the fishing effort allocation by restricting access to some areas for ICES SDs 24, 25 and 26, partly because the impact in these areas is limited (the baseline conditions for more long-lived fauna (3-10y) are close to carrying capacity in the undisturbed state). Conversely, the effect of a spatial cut in mitigating the pressure on the seafloor in ICES area IIIa (the Kattegat) in the simulations is apparent and, to a lesser extent, in SD 22 and 24, as well, in which RBS reached an equilibrium more quickly.

The measured impact at the end of the simulation period showed that in the central Baltic, only a minor fraction of the localities had degraded RBS for the total community in the baseline (Fig. $3 g$, $\mathrm{k}$, and o), and the rest is not impacted at all or is fully recovered (RBS at 1). Conversely, approximately $1 / 3$ of the localities were affected in Kattegat area IIIa (Fig. 3), as a result of a high swept area ratio (SAR, $>1$ if the locality is entirely swept at least once a year). In Kattegat area IIIa, the change in fishing pressure induced by the largest spatial restriction led most of the localities to reach either an RBS of 1 or close to 0 (Fig. 3). Hence, the baseline has an RBS of ca. 0.29 , while the $50 \%$ cut (EEZ scenario) has an RBS of ca. 0.37 . This change would correspond to a recovery of approximately $27 \%$. Additionally, the effect on the RBS was minor in areas 22, 24, and 25 (Fig. 3), and the central Baltic Sea did not show many cells with more degraded RBS from the spatial measures. Most of the cells have an RBS close to 1 for the total community, thus pulling the subregion RBS average towards 1 .

Hence, we found that in central Baltic, the gradient of intensification in displacing the effort towards the core fishing grounds did not imply an overall improvement in the RBS (i.e., less than a $1 \%$ improvement in SDs 22, 24, 25 and 26, irrespective of the intensification, Fig. 4b). We observed a slight gain in the RBS in the closed areas only, given that the overall gain was cancelled out with the accompanying degradation of the RBS in the remaining open areas where the pressure increased (supplementary materials SM3). In addition, the improvement in the RBS tended to be the highest in the simulations for scenarios in which 50\% effort on the peripheral areas was cut and displaced (Fig. 4). However, this gain applied locally, without leading to a striking overall gain (Fig. 33). Hence, the spatial plans for the core ground were beneficial to the closed areas, but they did not impact or, at worse were harmful, at the overall scale (Fig. 4).

\subsection{Spatial management measures and their effects on fishery economics}

We measured the impact on the economic performance with the contribution margins, which is defined as the income from landings minus variable operation costs for fishing. Restricting the netters led to a large net loss in the central Baltic contribution margins (up to -38\% in SDs 22, 24), affecting both netters and trawlers (Fig. 4a) and causing a small decline in the RBS (-3\% in SDs 22, 24, 25 and 26). By contrast, restricting netters was the most beneficial situation in SD26 for the netters economy. Regarding the bottom-contacting gear activities, on the one hand, applying the spatial plans where the core grounds were first closed was found to be harmful to the contribution margin of the trawlers 
compared to the baseline (up to - 8\%) without changing the RBS $(<1 \%)$. However, applying the spatial plans to the peripheral areas led to trends in different directions depending on the concerned area, whichwhich is masked if we disregard the areas. For this latter finding, we understand that the applied spatial measures increase the contribution margins along with the effort displacement gradient on the peripheral areas (Fig. 4). The best-scenario outcomes were provided by the effort cut of $50 \%$ in peripheral fishing, which had the highest contribution margin improvement $(+11 \%)$ and the most significant RBS improvement $(+15 \%)$ regardless of the type of activity.

In viewing the outcomes by area (Fig. 4a) the overall gain in the economic contribution margins along with the spatial cut along the peripheral areas was, as in the RBS, primarily due to improvements in the Kattegat $(+17 \%$ in the margin, $+14 \%$ in RBS). This improvement occurred because both the shortlived and long-lived benthos status increased (Fig. 2). In the central Baltic, both the landing volumes and incomes from the landings decreased compared to the baseline (up to $-7.7 \%$ in SD 22, 24, 25, and 26, -A2.1-A2.5 Supplementary Materials SM3). In comparison, the RBS did not improve significantly $(<1 \%)$.

As expected, the mobile bottom-contacting gear activities were responsible for most of the landing volume and income from landings in the Baltic Sea but were less efficient than the netters regarding the energy use efficiency (value per unit effort, see Table in Annexes A2.2). Concentrating the fishing effort on fewer areas caused the total spatial footprint to be much less extended, and the simulated spatial origin of the catches changed accordingly (Fig. 5). By contrast, the restriction on netters moved catches out of restricted areas and led to an overall increase in catches for all the other grounds (Supplementary Materials SM3). A general increase in catches in all areas is the result of a change in the trip patterns (Fig. 6) and was obtained when netters were being restricted as a consequence of technical interactions between netters and trawlers. Hence, more and less efficient fishing efforts were deployed by bottom trawlers when the netters were being displaced (Fig. 6). Netters were also less efficient when we integrated the outcomes over the 5-year period. The trip pattern for netters (Fig. 6) changed for fewer but longer trips compared to the baseline, with these trips being less efficient at catching fish as indicated by the lower effective average catch rate, with the overall landings being lower than in the baseline. However, the income is only slightly reduced over the five-year period, given that the vessels are more efficient at using fuel. Conversely, the effort displacement towards the core grounds increased the income from better energy use and less steaming time and searching, even if the catch rates were also lower than they were in the baseline situation. Additionally, a positive interaction arose for netter economic performance this time when the mobile bottom-contacting gears were also displaced to the detriment of the economic performance of bottom trawlers.

All the scenarios led to decreased income inequality for bottom trawlers and netters (Fig. 6), likely because the vessels are forced to visit the same areas. However, some differences resulted from the distributional economic effects the spatial measures have on the respective revenues of the fishing harbour communities (Fig. 7). There was an unequal distribution of adverse effects, with the restriction on nets more heavily affecting the western Baltic (SD22) and the Kattegat harbour communities (Fig. 7). The fishing peripheral cuts in spatial fishing efforts in bottom trawling more adversely affected the communities with a port in the ICES 26 area while providing more benefits to ports in Kattegat (Fig. 7). A synergic effect appears to occur when restrictions on both netters and bottom contact gear apply simultaneously, attenuating the loss in income of the harbour communities affected by the restrictions on nets. In addition, a more substantial gain in the marginal contribution is anticipated for subarea IIIa from a larger landing volume and higher value per fuel unit.

\subsection{Spatial management measures and their effects on sustainable fishing}


A gain or loss from spatial restrictions affected both netters and trawlers, even if the restrictions did not apply to them directly during the simulation, suggesting that stock effects occur behind the scene as a result of lower fishing mortality. Hence, harvested stocks in better shape with higher biomasses benefited both types of fishing activity. The intensification of the spatial restriction on bottomcontacting gear activities was beneficial to the stocks overall, showing increased final biomasses and lower fishing mortalities compared to the baseline (Table 3).

In contrast, technical interactions, such as higher discard rates from displaced netters, penalising all the fishing agents, who lost future fishing opportunities (Table 3). The loss of fish landings is substantial when the simulations implement the restrictions on netters. Hence, restricting nets increased the overall spatial extent of the effort deployed by the entire fleet (i.e., netters plus trawlers). This increase led to an unexpected increase in the amount of unwanted fish that resulted from the greater fishing effort required to catch the quotas. However, restricting netters spatially led to less bird bycatch (Table 3). Most of the area where birds are distributed is being closed to fishing in this scenario, apart from the $10 \mathrm{~km}$ strip around the closed sites. The effort displacement towards the outside of the closed area did not lead to the capture of the same number of animals; therefore, the restriction is efficient in this respect, as long as a $10 \mathrm{~km}$ strip is justified. Notably, the simulation outcomes showed a change in harbour porpoise fatalities (Table 3). The displacement of netter efforts from the restricted areas did, on a few occasions, increase the bycatch of harbour porpoises outside the closed areas. However, there was an apparent net gain in the overall population biomass of harbour porpoises when the trawlers were also spatially restricted to core areas (Table 3). Lower unwanted catches of harbour porpoises by netters were the result of decreasing the overall fishing effort of netters as a side effect of the side peripheral cut in fishing effort management applied to vessels using bottom-contacting gears. This effort reduction caused the primary Baltic fish stocks targeted by fishing to develop higher biomass levels. Spatial restrictions incidentally increased the catch rates of fish stocks in areas fished by netters (Supplementary Materials SM3). As a result, the harbour porpoise population is larger than it is in the baseline because less effort is needed by the fisheries to catch their quotas when the fish stocks are recovering, because they are partly protected from the spatial cut and displacement of fishing effort.

Table 3. Simulation outcomes on biological indicators (fishing mortality F, spawning stock biomass SSB, and landings or incidental catches) for selected scenarios, as averaged over the replicates and expressed as ratios over the baseline estimates on the final simulation year. The ratios are logtransformed, meaning that 0 is no effect, a positive value is a smaller value for the baseline, and vice versa. Biological indicators are produced for the stocks with stock number dynamics being explicitly simulated. The harbour porpoise stock refers to the one present in the western Baltic sea and the Kattegat (see annexes). )

\begin{tabular}{lllll}
\hline Scenario & Target Stock & Fog(F/ & Log(SSB/ & Log(Landings/ \\
Baseline & COD.kat & 0 & 0 & 0 \\
Restriction on nets & COD.kat & -0.11 & 0.025 & 0.178 \\
Bottom-gears 10\% cut (EEZ) & COD.kat & 0.095 & 0.419 & 0.425 \\
Bottom-gears 20\% cut (EEZ) & COD.kat & -0.196 & 9.326 & 2.615 \\
Bottom-gears 30\% cut (EEZ) & COD.kat & -0.764 & 10.628 & 3.154 \\
Bottom-gears 50\% cut (EEZ) & COD.kat & -1.455 & 11.997 & 3.704 \\
Baseline & COD.2224 & 0 & 0 & 0 \\
Restriction on nets & COD.2224 & -1.043 & -3.679 & 0.024
\end{tabular}




\begin{tabular}{|c|c|c|c|c|}
\hline Bottom-gears $10 \%$ cut (EEZ) & COD.2224 & 0.079 & 0.388 & 0.632 \\
\hline Bottom-gears $20 \%$ cut (EEZ) & COD.2224 & 0.061 & 0.663 & 0.599 \\
\hline Bottom-gears $30 \%$ cut (EEZ) & COD.2224 & -0.012 & 0.763 & 1.382 \\
\hline Bottom-gears $50 \%$ cut (EEZ) & COD.2224 & 0.000 & 0.919 & 2.149 \\
\hline Baseline & HER.3a22 & 0 & 0 & 0 \\
\hline Restriction on nets & HER.3a22 & 4.067 & -4.517 & -1.18 \\
\hline Bottom-gears $10 \%$ cut (EEZ) & HER.3a22 & -0.043 & 0.15 & 0.01 \\
\hline Bottom-gears $20 \%$ cut (EEZ) & HER.3a22 & -0.089 & 0.177 & 0.074 \\
\hline Bottom-gears $30 \%$ cut (EEZ) & HER.3a22 & -0.163 & 0.232 & 0.058 \\
\hline Bottom-gears $50 \%$ cut (EEZ) & HER.3a22 & -0.082 & 0.214 & 0.059 \\
\hline Baseline & HER.2532 & 0 & 0 & 0 \\
\hline Restriction on nets & HER.2532 & -0.143 & 0.021 & 0.003 \\
\hline Bottom-gears $10 \%$ cut (EEZ) & HER.2532 & 0.025 & 0.007 & 0.018 \\
\hline Bottom-gears $20 \%$ cut (EEZ) & HER.2532 & -0.156 & 0.015 & -0.114 \\
\hline Bottom-gears $30 \%$ cut (EEZ) & HER.2532 & -0.125 & 0.039 & -0.098 \\
\hline Bottom-gears $50 \%$ cut (EEZ) & HER.2532 & -0.082 & 0.015 & -0.06 \\
\hline Baseline & PLE.2123 & 0 & 0 & 0 \\
\hline Restriction on nets & PLE.2123 & -0.046 & -0.004 & -0.052 \\
\hline Bottom-gears $10 \%$ cut (EEZ) & PLE.2123 & -0.05 & 0.135 & 0.108 \\
\hline Bottom-gears $20 \%$ cut (EEZ) & PLE.2123 & -0.09 & 0.199 & 0.145 \\
\hline Bottom-gears $30 \%$ cut (EEZ) & PLE.2123 & -0.084 & 0.226 & 0.175 \\
\hline Bottom-gears $50 \%$ cut (EEZ) & PLE.2123 & -0.117 & 0.293 & 0.153 \\
\hline Baseline & PLE.2432 & 0 & 0 & 0 \\
\hline Restriction on nets & PLE.2432 & 0.008 & 0.102 & 0.034 \\
\hline Bottom-gears $10 \%$ cut (EEZ) & PLE.2432 & -0.433 & 0.621 & 0.08 \\
\hline Bottom-gears $20 \%$ cut (EEZ) & PLE.2432 & -0.511 & 0.72 & 0.098 \\
\hline Bottom-gears 30\% cut (EEZ) & PLE.2432 & -0.561 & 0.791 & 0.113 \\
\hline Bottom-gears $50 \%$ cut (EEZ) & PLE.2432 & -0.659 & 0.865 & 0.12 \\
\hline Baseline & SPR.2232 & 0 & 0 & 0 \\
\hline Restriction on nets & SPR.2232 & 0.462 & -0.213 & 0.479 \\
\hline Bottom-gears $10 \%$ cut (EEZ) & SPR.2232 & -0.003 & 0.013 & -0.042 \\
\hline Bottom-gears $20 \%$ cut (EEZ) & SPR.2232 & -0.002 & 0.022 & -0.019 \\
\hline Bottom-gears 30\% cut (EEZ) & SPR.2232 & -0.011 & 0.022 & -0.054 \\
\hline Bottom-gears $50 \%$ cut (EEZ) & SPR.2232 & -0.035 & 0.029 & -0.074 \\
\hline Scenario & Incidental catch & $\begin{array}{l}\text { Log(F/ } \\
\text { Fbaseline) }\end{array}$ & - & $\begin{array}{l}\text { Log(catch/ } \\
\text { catch_baseline) }\end{array}$ \\
\hline Baseline & H. Porpoise & 0 & - & 0 \\
\hline Restriction on nets & H.Porpoise & -0.068 & - & -0.035 \\
\hline Bottom-gears $10 \%$ cut (EEZ) & H.Porpoise & -0.07 & - & -0.03 \\
\hline Bottom-gears $20 \%$ cut (EEZ) & H.Porpoise & -0.11 & - & -0.058 \\
\hline Bottom-gears $30 \%$ cut (EEZ) & H.Porpoise & -0.134 & - & -0.074 \\
\hline Bottom-gears $50 \%$ cut (EEZ) & H.Porpoise & -0.196 & - & -0.112 \\
\hline Baseline & Birds & - & - & 0 \\
\hline Restriction on nets & Birds & - & - & -0.220 \\
\hline
\end{tabular}




\begin{tabular}{lllll} 
Bottom-gears $10 \%$ cut (EEZ) & Birds & - & - & 0.002 \\
Bottom-gears $20 \%$ cut (EEZ) & Birds & - & - & 0.000 \\
Bottom-gears $30 \%$ cut (EEZ) & Birds & - & - & -0.004 \\
Bottom-gears 50\% cut (EEZ) & Birds & - & - & -0.023 \\
\hline
\end{tabular}

\section{Discussion}

We developed a spatial model of fish, fisheries, and benthos dynamics to identify the seafloor habitats that are most at risk from fishing impacts and the management options for mitigating this potential seafloor impact. The modelling platform is a contribution to impact assessments on the social and economic impacts of alternative pathways to achieve environmental targets for fish stocks and benthic habitats. The investigation reports on the costs and effects of mitigating or displacing the fishing pressure, also including distributional economic effects on fishing agents. We then identified whether the species targeted by fishing can still be exploited sustainably, also considering possible conjugated effects from other spatial measures for minimising incidental catches of birds and marine mammals. Finally, we identify how fisheries economics are affected by the management and natural dynamics of the system. We applied the modelling framework to the Baltic Sea and to the Kattegat, which is a transitional ecosystem towards the more saline North Sea.

\section{Management scenarios and seafloor status}

Our findings indicate that in the Baltic Sea, the dominance of short-lived benthic species indicates that little significant evidence is found for improvements in the benthic community from the displacement of fisheries activity away from peripheral areas. The increase in the relative benthic state is insignificant across the central Baltic region, even if reducing the spatial fishing extent significantly. Conversely, we anticipate a better benthic status in the Kattegat from concentrating the fishing effort in a smaller area. This region-specific difference arises from the different types of benthic communities that are affected by both environmental gradients and fishing pressure (Bonsdorff 2006, van Denderen et al. 2015, Hiddink et al. 2018, and references therein) as well as the initial benthic status in the two areas. In the Kattegat area, the baseline state of the benthic communities is far from the theoretical carrying capacity due to a historical high trawling intensity (Bartolino et al. 2012, Pommer et al. 2016). The potential for animals to live longer (also reflecting longer recovery times) than what the current frequency of fishing impacts allows is considerable in most of the habitat types in the Kattegat.

Furthermore, in the already frequently fished area in Kattegat, to where the pressure is redirected in the simulation, the benthos status cannot degrade much further. Less impact on already trawled areas occurs because the model assumes that the first fishing pressure has the highest impact, i.e., the larger the biomass is before the depletion event, the larger the depletion effect. According to the response curves, the most substantial improvement in RBS will, therefore, be obtained by cutting and displacing activity from areas with intermediate benthic status levels. This finding is in contrast to the Baltic Sea, where the lack of improvement in the overall RBS is a result of the central Baltic Sea having large areas that are unfished and of the central Baltic Sea being dominated by short-lived fauna (ICES 2019a). Short-lived fauna recovers relatively quickly when impacted by fishery pressure (following the estimates of Hiddink et al. 2018) they are more resilient than those of the more saline 
northern sea areas (Sköld et al. 2018; Nielsen et al. in prep). In the Baltic Sea, decades of bottom fishing coincided with natural disturbances and strong environmental gradients in certain areas to shape the central Baltic benthic communities (Nielsen et al. in prep). Due to the high level of environmental disturbance, such as hypoxia and a strong salinity gradient towards low salinity, the benthic community might be naturally and continuously filtered out to the benefit of short-lived species (Hiddink et al 2006, Hiddink and Coleby 2012, Oberle et al. 2016).

There are, however, certain caveats to the current approach that must be considered. As in Hiddink et al. (2019) and van Denderen et al. (2020), the longevity trait was used here as the primary factor to assess the recovery of the benthic species to trawling, and its use may overlook other significant factors that could affect the benthic and overall ecosystem dynamics. For example, we ignored the possible importance of a few long-lived keystone benthic species for predators and food web function. We also faced a well-known issue of establishing a correct baseline for the benthic community, i.e., the historic/pristine conditions in which the benthic community may have included other species, given the few habitats that can be trawled that are left untrawled. It is difficult to find areas that not affected by any fishing (e.g., Bolam et al. 2017). To gain a broader understanding of the dynamics of the ecosystems, however, more effort in collecting benthos data across different habitat types will be required, including information on various benthic life-history traits, survival and recoverability, in addition to environmental and physical habitat conditions (Rijnsdorp et al. 2020). New data will enable the better fitting of different models that account for these effects (Nielsen et al. in prep). However, looking at the longevity traits (maximum animal lifespan) to measure the fishing impacts on the benthic community has been a convenient and operational approach that can easily be incorporated into assessment routines, as discussed in van Denderen et al. (2020). The actual animal lifespan we observe should relate to the frequency of trawling events, with a degree of disturbance expected to be inversely proportional to this frequency (Rijnsdorp et al. 2016). The longevity approach based on the evaluation assumes that the relative benthic status reflects the full carrying capacity of the habitat when the habitat has no fishing pressure $(<0.1 \mathrm{SAR})$. In addition, we would expect that some areas are not trawled because they are not suitable for fishing, and therefore they could have different benthic communities.

The relative benthic status indicator can be used to prioritize conservation areas that are expected to be most impacted in community biomass, relative to their carrying capacity. Yet, it is not clear if the habitats that may have a higher value by themselves in the structure and functioning of the benthic ecosystems may be some of those with low carrying capacities but high diversity, or those with a high carrying capacity but poor diversity. Environmental managers usually prioritise the protection of high biodiversity areas. In this regard, the relative benthic status might still be a good indicator given that we based the information on the total benthic biomass and the relative abundance of different longevities, although the relationships between faunal longevity and biodiversity have not been tested. In this case, we would expect that high community biomass coincides with communities in which the body size distribution, age structure, and numbers of the benthic fauna are close to natural levels. The biomass is linked to the overall functioning of the ecosystem and correlates to the energy flow traversing food webs (Maureaud et al. 2019). The biomass also correlates to other ecosystem processes that are linked closely to the biomass such as nutrient cycling, bioturbation, and food provisioning for fish and sea birds (Bolam et al. 2002).

Providing fisheries science with long-term time series and studies on relationships between the benthos status, the fishing and other possible drivers requires a long-term monitoring scheme for benthos sampling and reinforcing the quality of this sampling. Current estimation of benthic longevity are based on grabs and corers that sample small in- and epifauna (e.g., Grabowski et al. 2014).The 
sampling efficiency differs when catching various components of the communities, including for the catching of animals from different size groups. (McLaverty et al. 2020) and gears that sample bigger animals will catch a more significant fraction of long-lived fauna. The integration of other sampling gears will capture other components of the benthic community and likely strengthen the overall assessment. .

In addition to natural and fishing disturbances, other types of pressures may conjugate to affect the benthic habitats, including frequent natural or human-induced hypoxia events on central Baltic benthos communities (Bossier et al. 2018; van Denderen et al. 2020). Even if these effects may be modest in an area with short-lived species, hypoxia is known to influence the central Baltic benthic communities significantly as well as the opportunities of fish stocks to develop there (Diaz and Rosenberg 1995, Tornroos et al. 2015). For demersal fish species, hypoxia-induced habitat compression can lead to crowding and increase competition for prey, especially for juvenile fish, potentially resulting in decreased body conditions (Casini et al. 2016). For benthos animals, a recent study (van Denderen et al. 2020) has shown how to incorporate the hypoxia effects into the assessment, even if mitigating the impact of nutrient accumulation into the sediments on the ecosystems would require several generations of fish and benthos.

It may also be crucial to account for the other ecosystem components that drive the benthos dynamics. These drivers include the interactions with benthivorous fish, provided that the benthos prey availability positively influences the fish growth (Hinz et al. 2017) while these fishes have some diet preference that will in turn affect the overall benthos depletion differently (Hiddink et al. 2016). The habitat structure may affect fish and the predation effect on the benthos (Collie et al. 2017). Our simulations ignored the long-term effects that would arise from food web interactions between the benthos and the fish and habitat ecosystem components. Several authors found or suggested increasing benthic invertebrate abundance and biodiversity with increasing bottom trawling fishing intensity (van Denderen et al. 2013, Lambert et al. 2017, Sköld et al. 2018) in the longer term. This effect is most likely due to fishery-induced reductions in flatfish predators on the invertebrates (Hiddink et al. 2016). On a broader scale, human-induced warmer temperatures that create a change in the hydrological conditions of the Baltic Sea is considered one of the primary pressures leading to the recruitment failure of individual Baltic fish stocks (MacKenzie et al. 2012).

The local physical habitat structure and connectivity between patches will also play a role by favouring the recolonisation of the benthos from the surrounding areas and habitats, i.e., the level of connectivity between areas (e.g., Bendtsen and Hansen 2013). These parameters are likely to increase our perception of the fishing impacts on the recovery rates, with different aspects depending on the habitats and the benthic communities (ICES 2019a). Hence, a precautionary approach based on the current analysis suggests that the fishing effort should be limited to the existing trawled areas so that non-impacted regions are not exposed to activities that could result in a dramatic degradation of their current status.

\section{Management scenarios and fisheries economics}

One striking outcome of our simulation was the positive reaction of the exploited stocks to the tested management scenarios, including the increasing trend that was observed for the relative benthic status and fisheries economics. This latter trend occurred primarily for situations restricting both passive and bottom-contacting gears. Higher harvested stock levels can address both viable, sustainable fishing and environmental concerns such as protecting the seafloor integrity. However, in most of the scenarios tested here, the simulations demonstrated that fishing effort displacement could negatively affect both the seafloor integrity and the fishery economic performance when technical and biological interactions arose. For example, our simulations showed that the fisheries using bottom-contacting 
gears in the central Baltic would more likely have their economy adversely affected by the spatial measures in the short-term. In addition, a modest improvement in the benthic habitat status is anticipated. Therefore, displacing fisheries from their core grounds poses the risk of increasing the total trawling footprint and interactions with other fisheries and sectors. As shown in our study, a conflict arose between the displaced passive gears and the mobile bottom gears when each unit of fishing effort was less efficient at catching the target species, requiring more time to catch the fish quotas. As a consequence, restricting passive gear alone was the worst scenario for the fishery economic performance, and it also reduced the benthic status to the lowest level in the central Baltic.

In our scenarios, we did not allow any fishing effort to be displaced from the core fishing grounds to operate on previously less trawled or untrawled areas. This change in effort distribution is considered unlikely because we do not expect the vessels to fish new areas. We make this assumption because of the distribution of the target species, and therefore the suitable areas to fish, have been shown to correlate strongly with constant spatial patterns in environmental factors (e.g., Diesing et al. 2013). Visiting unknown areas also depends on where the fishers are used to operating, where they can operate the fishing gear given suitable bottom types or mobility, and where bottom fishing is allowed (> $4 \mathrm{~nm}$ of the coast in the Baltic). A change would require the fishing to not be constrained anymore by unsuitable bottom types or by specific spatial allowance regulations. For example, the footprint might increase if the control of the area access is changed, or if innovative gear is developed to operate on previously unsuitable sea bottom types (Sala et al. in review). However, if our findings show that there is not much to gain in seafloor integrity by concentrating fishing pressure, as shown in our results, there might be a great deal to lose from displacing fishing efforts outside historical limits. Displacing the effort outside the past limits will likely degrade the future benthos state by allocating additional pressure to lightly fished areas in a good benthic state.

The long-term effects of the management measures are uncertain regarding fishery economics. On the one hand, the short-term adverse effects on individual vessel economics might balance with more long-term positive effects on the stock development of the targeted species. On the other hand, we might expect the adverse effect on fisheries economics to be greater in reality, given that the maintenance of the same level of catches would likely have been overestimated in our simulations. The fishing vessels are assumed to have free access to less frequently fished areas to comply with spatial management. Accordingly, these vessels operate in other defined fishing grounds according to their traditional fishing patterns, where they will face increased crowding and competition for resources (e.g., Poos and Rijnsdorp 2007). Within the five-year time horizon, the competition could create lower catch rates because of increased resource depletion that would result from the increased fishing intensity. Limiting access to the traditional core grounds is also an option that could reduce the catch rates for target species, therefore making the fishing less efficient, which translates to an increased spatial footprint when fishers seek to maintain their catch levels. In addition, most of the catch rates in the simulations were not changing dynamically in the model along with a change in stock abundance and density for all stocks, because only the most important and studied stocks had data available. We therefore assumed stable catch rates as a lack of an alternative for most of the harvested stocks. If this assumption is realistic (Kraak et al. 2008, Oostenbrugge et al. 2008), catch rate hyperstability largely occurs because fishing is becoming more efficient along a reduction in effort but also for other reasons, especially declining stocks. Hence, the next priority would be to include alternative hyperstability models wherever proper stock data are not made available.

The quality of the fisheries data used as input creates additional inherent uncertainties. For example, the fisheries data are dependent on the accuracy of the EU fleet register, reporting the number of vessels per home harbour together with the vessel specifications (length and $\mathrm{kW}$ ). However, suspicion 
is rising about the possible widespread underreporting of the actual engine power in the EU fleet register (EC 2019). This biased reporting would lead not only to underestimates of the vessel fuel consumption but also the size of the gear that can be towed by the vessels. New fisheries knowledge would also be required to strengthen the evaluation, especially for estimating the bycatch risk (KindtLarsen et al. 2017; Christensen-Dalsgaard et al. 2019; Glemarec et al., 2020). Precisely because, by nature, bycaught species are not targeted, we had difficulty in retrieving thorough and consistent data for the full population dynamics and catches. Ongoing studies should yield more accurate data concerning the marine bird and mammal species distribution, the catch rates, and the high-risk areas for these catches.

\section{Policy implications}

Managers are keen to integrate the existing relevant knowledge into tools that can be used during the annual advisory process of scientific advisory bodies. To this end, we informed the modelling platform with data collected from within existing monitoring programmes (see Table 1) and benchmarked the cost-effectiveness of alternative management measures and spatial plans that affect fisheries. For example, while they do not appear to bring any immediate benefit by diminishing the fishing effort on already trawled areas in the central Baltic, our findings suggest that it could be most relevant to limit fishing in areas impacted by an intermediate level of fishing pressure, as associated with no-go areas to maintain a network of untrawled areas. An appropriate network of well-connected habitat types may also enable a stable and 'natural' benthic community to develop, thereby providing some guidance in setting threshold values for a good status. This approach could maintain a balanced level of fisheries activities in the highly productive zones without risking the displacement of higher activity to areas that were already less strongly impacted by bottom contacting gears. Alternatively, instead of displacing the fishing pressure, an overall reduction in fishing pressure, for example, that obtained by reducing the contact of the fishing gears with the seafloor, could also help to close the gap towards achieving a good environmental status in the Baltic Sea. On this basis, and considering the resulting cost of these options, policymakers may decide whether it is worth implementing these management measures or not. This scenario-testing approach is likely to facilitate social acceptance/compliance with the identified suitable spatial measures. Spatial measures are truly not very well received by fishers compared to other options, and the level of trust between the public sector and fishers has recently decreased (Soma et al. 2018). In this context, among the possible ways to implement a reduction in pressure, the ongoing revision of the EU MSFD might also lead to freeing a fixed proportion of the seafloor area from fishing, either for each EEZ or each marine habitat, an option that can be tested in future studies. Individual habitat quota system proposed by Holland and Schnier (2006) could also be a valuable alternative to facilitate the acceptance of the spatial mitigation tool. These quotas would use economic incentives to encourage habitat conservation, in which fishers obtain credits that reflect the amount of habitat damage that they cause by trawling, to make it economically less attractive to fish in the most sensitive areas. Hence, the further development of this framework testing on spatial restriction options will continue to make the science more comprehensive for policymakers and stakeholders for better and more sustainable governance and scientific advice. The research performed to date has been presented at several HELCOM Working Groups and is closely linked to the detailed methodological description that is being developed by the advisory body (ICES 2019a). This type of decision-supporting tool will greatly contribute to integrating the transboundary context for consistent and coordinated measures across the Baltic Sea sub-regions for more coherent and coordinated approaches within marine regions and subregions, and 
it will create a direct link from fisheries management (CFP) to marine environment management (MSFD).

\section{Conclusion}

We identify a need to address environmental and fisheries policies and their descriptors in relation to their sustainability on an integrated basis using similar management measures. Using a solid scientific basis, the integrative modelling platform presented through a Kattegat and Baltic Sea application represents an enhancement of our knowledge on interlinked fisheries and benthos dynamics, including changes in the spatial distribution patterns and subsequent fishing opportunities. In this instance, we estimated the effects on the seafloor given different management scenarios, with a focus on the spatial management of fisheries. When evaluating the management performance, we showed that for the same fishing capacity level, and in being specific to the central Baltic Sea, a displacement of effort would likely negate any attempt to improve the overall relative benthic status through area closures in the central Baltic Sea. Additionally, these spatial measures are likely to affect the fishery economy adversely in the short run. An essential outcome of the presented integrated Baltic Sea model is the provision of a platform to detail an estimation of changes in the spatial fishing pressure in a way that is consistent with fisher behaviour. Accounting for individual flexibility is increasingly important as fishers become subject to new area-based management actions (e.g., the EU MSFD) in relation to more fish-stock oriented management measures (e.g., the EU CFP). In the context of an ecosystem-based approach to fisheries management, our approach has the ambition to inform the best fishing pressure allocation that corresponds to sustainable exploitation with the minimum impact on other components of the marine ecosystems. Communicating all these options to the relevant sectors and the broader society will contribute to more economically viable, profitable, and environmentally sustainable fisheries practices.

\section{Software}

The software is freely available for download on https://displace-project.org/blog/download/ and the dataset at https://github.com/frabas/DISPLACE_input_BalticSea for this particular application.

\section{Acknowledgements}

This work has been funded by the ACTION project ("Actions to evaluate and identify effective measures to reach GES in the Baltic Sea marine region"), a HELCOM coordinated project that is cofinanced by the EU (Grant agreement number: 110661/2018/794637/SUB/ENV.C2).

\section{References}

Bartolino V, Cardinale M, Svedäng H, Casini M, Linderholm HW, Grimwall A (2012). Historical spatiotemporal dynamics of eastern North Sea cod. Can J Fish Aquat Sci 69: 833-630

Bastardie, F., Nielsen, J. R., Ulrich, C., Egekvist, J., \& Degel, H. (2010). Detailed mapping of fishing effort and landings by coupling fishing logbooks with satellite-recorded vessel geo-location. Fisheries Research, 106(1), 41-53.

Bastardie, F., Nielsen, J.R., Miethe, T. 2014. DISPLACE: a dynamic, individual-based model for spatial fishing planning and effort displacement - integrating underlying fish population models. Canadian Journal of Fisheries and Aquatic Sciences. 71: 366-386.

Bastardie, F., Nielsen, J.R., Eigaard, O.E., Fock, H. O., Jonsson, P., Bartolino, V. 2015. Competition for marine space: modelling the Baltic Sea fisheries and effort displacement under spatial restrictions, ICES Journal of Marine Science. 72: 824-840. 
Bastardie, F., Angelini, S., Bolognini, L., Fuga, F., Manfredi, C., Martinelli, M., Nielsen, J. R., Santojanni, A., Scarcella, G., and Grati, F.. 2017. Spatial planning for fisheries in the Northern Adriatic: working toward viable and sustainable fishing. Ecosphere 8(2):e01696.

Bendtsen, J., Hansen, J.L.S. 2013. A model of life cycle, connectivity and population stability of benthic macro-invertebrates in the North Sea/Baltic Sea transition zone. Ecological Modelling. 267: 54-65.

Bolam, S. G., Fernandes, T. F., \& Huxham, M. (2002). Diversity, biomass, and ecosystem processes in the marine benthos. Ecological monographs, 72: 599-615.

Bossier S, Palacz AP, Nielsen JR, Christensen A, Hoff A, Maar M, et al. 2018. The Baltic Sea Atlantis: An integrated end-to-end modelling framework evaluating ecosystem-wide effects of human-induced pressures. PLoS ONE 13(7): e0199168.

Bonsdorff E. 2006. Zoobenthic diversity-gradients in the Baltic Sea: continuous post-glacial succession in a stressed ecosystem. Journal of Experimental Marine Biology and Ecology, 330: 383-391.

Casini, $\mathrm{M}$ et al. 2016. Hypoxic areas, density-dependence and food limitation drive the body condition of a heavily exploited marine fish predator. R. Soc. opensci. 3: 160-416.

Collie, J., Hiddink, J.G., van Kooten, T., Rijnsdorp, A.D., Kaiser, M.J., Jennings, S. and Hilborn, R. (2017), Indirect effects of bottom fishing on the productivity of marine fish. Fish Fish, 18: 619-637. doi:10.1111/faf.12193

Christensen-Dalsgaard, S., Anker-Nilssen, T., Crawford, R., Bond, A., Sigurðsson, G. M., Glemarec, G., ... \& Merkel, F. R. (2019). What's the catch with lumpsuckers? A North Atlantic study of seabird bycatch in lumpsucker gillnet fisheries. Biological Conservation, 240: 108278

Diaz, R.J.; Rosenberg, R. (1995). Marine benthic hypoxia: a review of its ecological effects and the behavioural responses of benthic macrofauna.

Diesing, M., Stephens, D., and Aldridge, J. 2013. A proposed method for assessing the extent of the seabed significantly affected by demersal fishing in the Greater North Sea. ICES Journal of Marine Science, 70: 1085-1096.

Dinmore, T. A., Duplisea, D. E., Rackham, B. D., Maxwell, D. L., and Jennings, S. 2003. Impact of a large-scale area closure on patterns of fishing disturbance and the consequences for benthic communities. ICES Journal of Marine Science, 60: 371-380.

EC, 1992. Council directive 92/43/EEC on the conservation of natural habitats and wild fauna and flora.

EC, 2013a. Regulation (EU) No 1380/2013 of the European Parliament and of the Council of 11 December 2013 on the Common Fisheries Policy, amending Council Regulations (EC) No 1954/2003 and (EC) No 1224/2009 and repealing Council Regulations (EC) No 2371/2002 and (EC) No 639/2004 and Council Decision 2004/585/EC

EC, 2013b. Science for Environment Policy - Thematic issue: Seafloor damage. https://ec.europa.eu/environment/integration/research/newsalert/pdf/45si_en.pdf

EC, 2016a. Regulation (EU) 2016/1139 of the European Parliament and of the Council of 6 July 2016 establishing a multiannual plan for the stocks of cod, herring and sprat in the Baltic Sea and the fisheries exploiting those stocks, amending Council Regulation (EC) No 2187/2005 and repealing Council Regulation (EC) No 1098/2007

EC, 2016b. Commission Implementing Decision (EU) 2016/1701 of 19 August 2016 laying down rules on the format for the submission of work plans for data collection in the fisheries and aquaculture sectors (notified under document C(2016) 5304)

EC, 2017. Commission Decision (EU) 2017/848 of 17 May 2017 laying down criteria and methodological standards on good environmental status of marine waters and specifications 
and standardised methods for monitoring and assessment, and repealing Decision 2010/477/EU (Text with EEA relevance)

EC, 2019. Study on engine power verification by Member States. European Commission, Directorate General for Maritime Affairs and Fisheries. doi: 10.2771/945320

Edrén, S.M.C., Wisz, M.S., Teilmann, J., Dietz, R. and Söderkvist, J. 2010. Modelling spatial patterns in harbour porpoise satellite telemetry data using maximum entropy. Ecography, 33: 698-708.

Eigaard, O. R., Bastardie, F., Hinzen, N. T., Buhl-Mortensen, L., Mortensen, P. B., Catarino, R., ... Rijnsdorp, A. D. (2017). The footprint of bottom trawling in European waters: distribution, intensity, and seabed integrity. ICES Journal of Marine Science, 74(3), 847-865.

Garcia, S.M.; Zerbi, A.; Aliaume, C.; Do Chi, T.; Lasserre, G. (2003). The ecosystem approach to fisheries. Issues, terminology, principles, institutional foundations, implementation and outlook. FAO Fisheries Technical Paper. No. 443. Rome, FAO. 2003. 71 p.

Glemarec, G.; Kindt-Larsen, L.; Lundgaard, L. S.; Larsen, F. (2020). Assessing seabird bycatch in gillnet fisheries using electronic monitoring. Biological Conservation, 243: 108461.

Gogina, M., Nygård, H., Blomqvist, M., Daunys, D., Josefson, A. B., Kotta, J., Maximov, A., et al. 2016. The Baltic Sea scale inventory of benthic faunal communities. ICES Journal of Marine Science, 73: 1196-1213.

Grabowski, J. H., Bachman, M., Demarest, C., Eayrs, S., Harris, B. P., Malkoski, V., ... \& Stevenson, D. (2014). Assessing the vulnerability of marine benthos to fishing gear impacts. Reviews in Fisheries Science \& Aquaculture, 22(2), 142-155.

HELCOM, 2018. HELCOM Activities Report - Implementation of the Baltic Sea Action Plan. Baltic Sea Environment Proceedings No. 154. Available at: http://www.helcom.fi/Lists/Publications/BSEP154.pdf

Hinz, H., Moranta, J., Balestrini, S., Sciberras, M., Pantin, J. R., Monnington, J., Zalewski, A., et al. 2017. Stable isotopes reveal the effect of trawl fisheries on the diet of commercially exploited species. Scientific Reports, 7.

Hiddink, J. G., Jennings, S., Kaiser, M. J., Queirós, A. M., Duplisea, D. E., and Piet, G. J. $2006 a$. Cumulative impacts of seabed trawl disturbance on benthic biomass, production, and species richness in different habitats. Canadian Journal of Fisheries and Aquatic Sciences, 63: 721736.

Hiddink, J. G., and Coleby, C. 2012. What is the effect of climate change on marine fish biodiversity in an area of low connectivity, the Baltic Sea? Global Ecology and Biogeography, 21: 637646.

Hiddink, J.G., Moranta, J., Balestrini, S., Sciberras, M., Cendrier, M., Bowyer, R., Kaiser, M. J., Sköld, M., Jonsson, P., Bastardie, F., Hinz, H. 2016. Bottom trawling affects fish condition through changes in the ratio of prey availability to density of competitors Journal of Applied Ecology. 53: 500-1510.

Hiddink, J.G., Jennings, S., Sciberras, M., Szostek, C.L., Hughes, K.M., Ellis, N., Rijnsdorp, A.D., McConnaughey, R.A., Mazor, T., Hilborn, R., Collie, J.S., Pitcher, C.R., Amoroso, R.O., Parma, A.M., Suuronen, P., Kaiser, M.J., 2017. Global analysis of depletion and recovery of seabed biota after bottom trawling disturbance. Proc. Natl. Acad. Sci. 114, 8301-8306

Hiddink, J. G., Jennings, S., Sciberras, M., Bolam, S. G., Cambiè, G., McConnaughey, R. A., ... \& Parma, A. M. (2019). Assessing bottom trawling impacts based on the longevity of benthic invertebrates. Journal of Applied Ecology, 56(5), 1075-1084.Holland, D., \& Schnier, K. E. (2006). Individual habitat quotas for fisheries. Journal of Environmental Economics and Management, 51(1), 72-92. doi:10.1016/j.jeem.2005.04.005

ICES, 2019a. Interim Report of the Working Group on Fisheries Benthic Impact and Trade-offs (WGFBIT), 12-16 November 2018, ICES Headquarters, Copenhagen, Denmark. ICES CM 


\section{8/HAPISG:21. 74 pp}

ICES, 2019b. Workshop on Tradeoffs Scenarios between the Impact on Seafloor Habitats and Provisions of catch-value (WKTRADE2). International Council for the Exploration of the Sea (ICES). ICES Scientific Report, No. 63, Vol.. 1 https://doi.org/10.17895/ices.pub.5598

ICES, $2019 \mathrm{c}$. https://www.ices.dk/sites/pub/Publication\%20Reports/Advice/2019/Special_Requests/eu.20 19.25.pdf

ICES. 2019d. Workshop on scoping for benthic pressure layers D6C2 -from methods to operational data product (WKBEDPRES1), 24-26 October 2018, ICES HQ, Copenha-gen, Denmark. ICES CM 2018/ACOM:59. 69pp.

Kindt-Larsen, L, Berg, CW, Tougaard, J, Sørensen, TK, Geitner, K, Northridge, S, Sveegaard, S \& Larsen, F 2016, 'Identification of high-risk areas for harbour porpoise Phocoena phocoena bycatch using remote electronic monitoring and satellite telemetry data', Marine Ecology Progress Series, vol. 555, pp. 261-271. https://doi.org/10.3354/meps11806

Jennings, S., Lee, J., and Hiddink, J. G. 2012. Assessing fishery footprints and the trade-offs between landings value, habitat sensitivity, and fishing impacts to inform marine spatial planning and an ecosystem approach. ICES Journal of Marine Science, 69: 1053-1063.

Kraak, S.B.M., Buisman, E.F., Dickey-Collas, M., Poos, J.J., Pastoors, M.A., Smit, J.P.G., Oostenbrugge, H.J. van, Daan, N. 2008. The effect of management choices on the sustainability and economic performance of a mixed fishery: a simulation study. ICES J Mar Sci 65: 697-712.

Lambert, G.I., Murray, L.G., Hiddink, J.G., Hinz, H., Lincoln, H., Hold, N., Cambié, G. and Kaiser, M.J. 2017. Defining thresholds of sustainable impact on benthic communities in relation to fishing disturbance. Scientific Reports 7: 5440, 15 pp.

Long, R. D.; Charles, A.; Stephenson, R. L. (2015). Key principles of marine ecosystem-based management. Marine Policy, 57: 53-60.

McLaverty, C., Eigaard, O.R., Gislason, H., Bastardie, F. Brooks, M.E., Jonsson, P., Lehmann, A., Dinesen, G.E. 2020. Using large benthic macrofauna to refine and improve ecological indicators of bottom trawling disturbance, Ecological Indicators. 110, 105881.

McConnaughey, Robert A., Jan G. Hiddink, Simon Jennings, C. Roland Pitcher, Michel J. Kaiser, Petri Suuronen, Marija Sciberras, et al. 2019. Choosing Best Practices for Managing Impacts of Trawl Fishing on Seabed Habitats and Biota. Fish and Fisheries https://doi.org/10.1111/faf.12431.

MacKenzie, B.R., Meier, H.M., Lindegren, M., Neuenfeldt, S., Eero, M., Blenckner, T., Tomczak, M.T. and Niiranen, S., 2012. Impact of climate change on fish population dynamics in the Baltic Sea: a dynamical downscaling investigation. Ambio, 41(6), pp.626-636.

Mazor, T. K., Pitcher, C. R., Ellis, N., Rochester, W., Jennings, S., Hiddink, J. G., . . Hilborn, R. (2017). Trawl exposure and protection of seabed fauna at large spatial scales. Diversity and Distributions, 23(11), 1280-1291.

Maureaud, A., Hodapp, D., van Denderen, P. D., Hillebrand, H., Gislason, H., Spaanheden Dencker, T., ... \& Lindegren, M. (2019). Biodiversity-ecosystem functioning relationships in fish communities: biomass is related to evenness and the environment, not to species richness. Proceedings of the Royal Society B, 286: 20191189.

Nielsen, J.R., Vastenhoud, B.J.M., Bossier, S., Møhlenberg, F., Bastardie, F., Christensen, A., Dinesen, G., Eigaard, O.R., Diekman, R., Darr, A. (In prep.). Habitat specific fishing impacts and thresholds compared to natural stressors for benthic invertebrate communities in a turbulent Baltic Sea environment. (In prep. for MEPS). 
Oberle, F. K. J., Swarzenski, P. W., Reddy, C. M., Nelson, R. K., Baasch, B., and Hanebuth, T. J. J. 2016. Deciphering the lithological consequences of bottom trawling to sedimentary habitats on the shelf. Journal of Marine Systems, 159: 120-131.

Oostenbrugge, H.J. van, Powell, J.P., Smit, J.P.G., Poos, J.J., Kraak, S.B.M., Buisman, E.F. 2008. Linking catchability and fisher behaviour under effort management. Aquatic Liv Res 21: 265273.

Pitcher, C.R., Ellis, N., Jennings, S., Hiddink, J.G., Mazor, T., Kaiser, M.J., Kangas, M.I., McConnaughey, R.A., Parma, A.M., Rijnsdorp, A.D., Suuronen, P., Collie, J.S., Amoroso, R., Hughes, K.M. and Hilborn, R. (2017), Estimating the sustainability of towed fishing-gear impacts on seabed habitats: a simple quantitative risk assessment method applicable to datalimited fisheries. Methods Ecol Evol, 8: 472-480.

Pommer, C.D., Olesen, M. and Hansen, J.L., 2016. Impact and distribution of bottom trawl fishing on mud-bottom communities in the Kattegat. Marine Ecology Progress Series, 548, pp.47-60.

Poos J. J., Rijnsdorp A. D. 2007. An "experiment" on effort allocation of fishing vessels: the role of interference competition and area specialization. Canadian Journal of Fisheries and Aquatic Sciences, 64: 304-313.

Rijnsdorp, A. D., Bastardie, F., Bolam, S. G., Buhl-Mortensen, L., Eigaard, O. R., Hamon, K. G., 558 Hiddink, J. G., et al. 2016. Towards a framework for the quantitative assessment of trawling 559 impact on the seabed and benthic ecosystem. ICES Journal of Marine Science, 73: i127i138.

Rijnsdorp, A.D., Buys, A.M., Storbeck, F. Visser, E. G.1998. Micro-scale distribution of beam trawl effort in the southern North Sea between 1993 and 1996 in relation to the trawling frequency of the sea bed and the impact on benthic organisms, ICES Journal of Marine Science, Volume 55, Issue 3, June 1998, Pages 403-419

Rijnsdorp, A.D., Hiddink, J.G., van Denderen, P D, Hintzen, N T, Eigaard, O R, Valanko, S, Bastardie, F, Bolam, S G, Boulcott, P, Egekvist, J, Garcia, C, van Hoey G, Jonsson, P Laffargue, P, Nielsen, J R, Piet, G J Sköld, M, van Kooten T, 2020. Different bottom trawl fisheries have a differential impact on the status of the North Sea seafloor habitats, ICES Journal of Marine Science, fsaa050, https://doi.org/10.1093/icesjms/fsaa050

Sala, A. et al. 2020. Technological innovations to reduce the impact of bottom gears on the seabed. Marine Policy, in review.

Sköld, M., Göransson, P., Jonsson, P., Bastardie, F., Blomqvist, M., Agrenius, S., Hiddink, J.G., Nilsson, H.C., and Bartolino. 2018. Effects of chronic bottom trawling on soft-seafloor macrofauna in the Kattegat. Marine Ecology Progress Series 586: 41-55.

STECF, 2018a. The 2018 Annual Economic Report on the EU Fishing Fleet (STECF-18-07). Publications Office of the European Union, Luxembourg, 2018, JRC112940, ISBN 978-92-7979390-5, doi:10.2760/56158

STECF, 2018b. Fisheries Dependent Information (STECF-18-11). Publications Office of the European Union, Luxembourg, 2018, JRC114717, ISBN 1831-9424, doi:10.2760/696153

Soma, K., Nielsen, J. R., Papadopoulou, N., Polet, H., Zengin, M., Smith, C. J., Eigaard, O. R., Sala, A., Bonanomi, S., van den Burg, S. W. K., Piet, G. J., Buisman, E., and Gümüş, A. 2018. Stakeholder perceptions in fisheries management - Sectors with benthic impacts. Marine Policy, 92: 73-85.

Tornroos, A., Bonsdorff, E., Bremner, J., Blomqvist, M., Josefson, A. B., Garcia, C., and Warzocha, J. 2015. Marine benthic ecological functioning over decreasing taxonomic richness. Journal of Sea Research, 98: 49-56.

Thrush, S. F., Ellingsen, K. E., \& Davis, K. (2016). Implications of fisheries impacts to seabed biodiversity and ecosystem-based management. ICES Journal of Marine Science, 73: 44-50. 
Trochta, J.T., Pons, M., Rudd, M.B., Krigbaum, M., Tanz, A. and Hilborn, R., (2018). Ecosystembased fisheries management: perception on definitions, implementations, and aspirations. PloS one, 13: e0190467.

Trimmer, M., Petersen, J., Sivyer, D. B., Mills, C., Young, E., and Parker, E. R. 2005. Impact of longterm benthic trawl disturbance on sediment sorting and biogeochemistry in the southern North Sea. Marine Ecology Progress Series, 298: 79-94.

van Denderen, P. D., van Kooten, T., and Rijnsdorp, A. D. 2013. When does fishing lead to more fish? Community consequences of bottom trawl fisheries in demersal food webs. Proceedings. Biological Sciences / The Royal Society, 280 (1769), 20131883.

van Denderen, P. D., Bolam, S. G., Hiddink, J. G., Jennings, S., Kenny, A., Rijnsdorp, A. D., \& van Kooten, T. (2015). Similar effects of bottom trawling and natural disturbance on composition and function of benthic communities across habitats. Marine Ecology Progress Series, 541, $31-43$.

van Denderen, P.D., Bolam, S.G., Friedland, R., Hiddink, J.G., Noren, K., Rijnsdorp, A.D., Sköld, M., Törnroos, A., Virtanen, E.A. and Valanko, S., 2020. Evaluating impacts of bottom trawling and hypoxia on benthic communities at the local, habitat, and regional scale using a modelling approach. ICES Journal of Marine Science, 77, pp.278-289. 


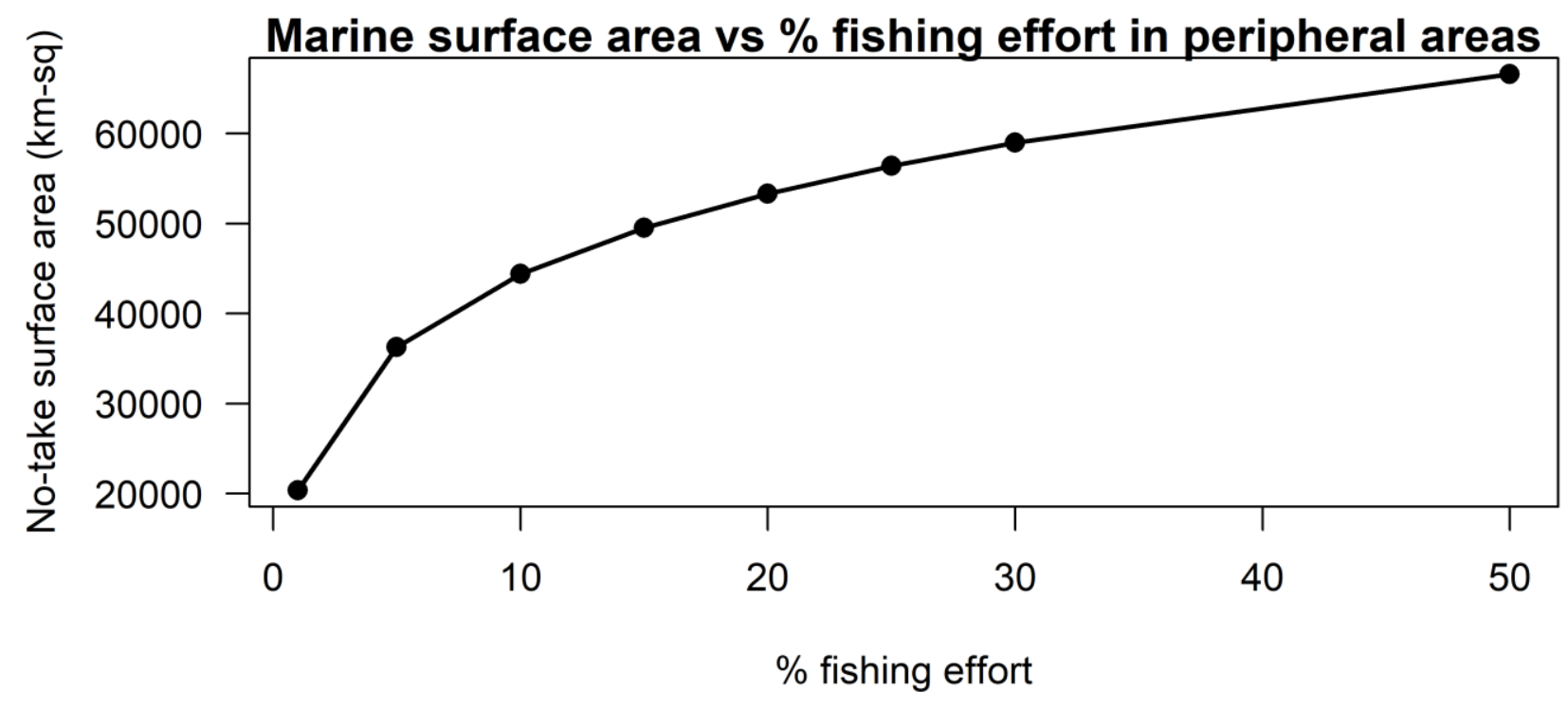

$30 \%$ of the fishing effort

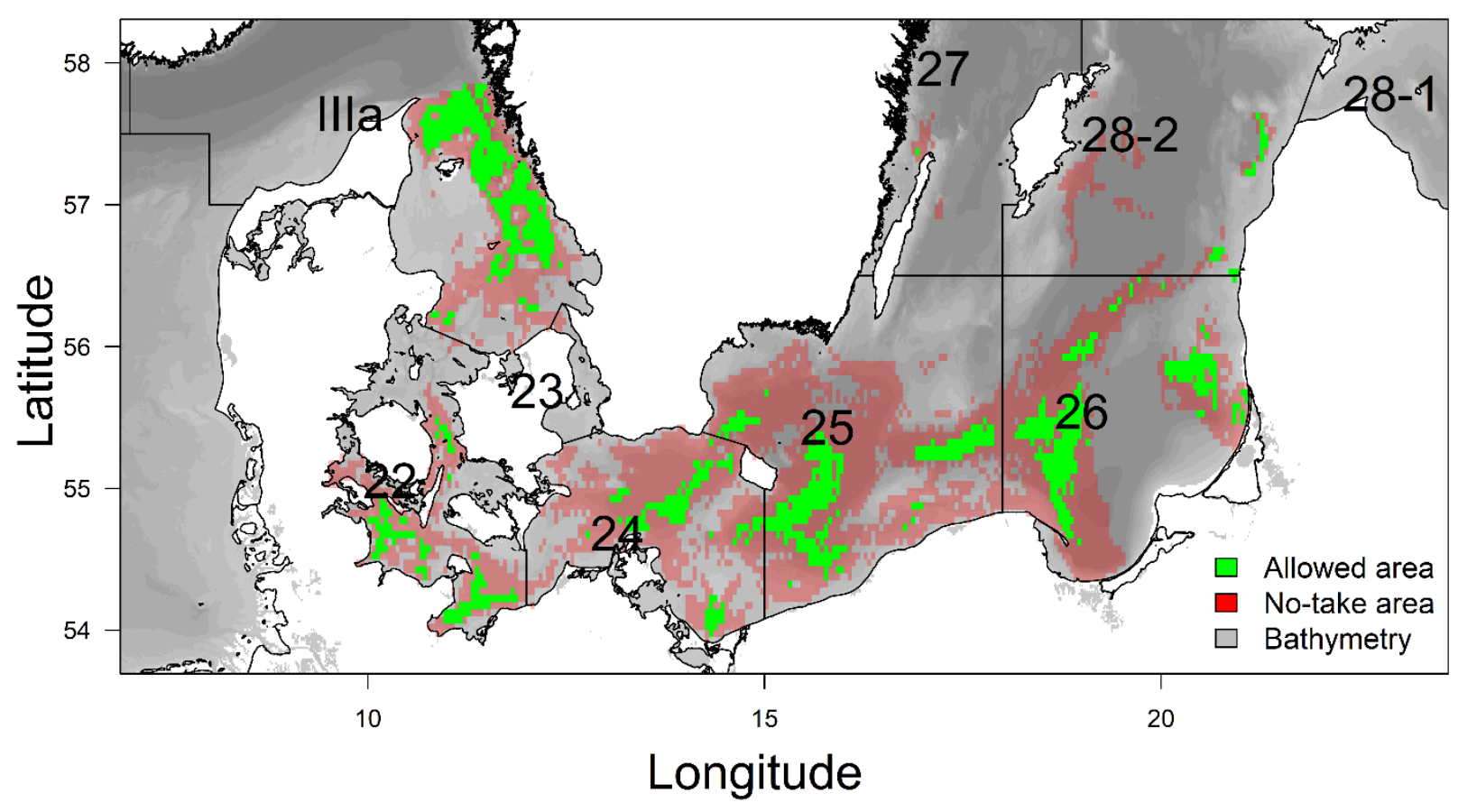




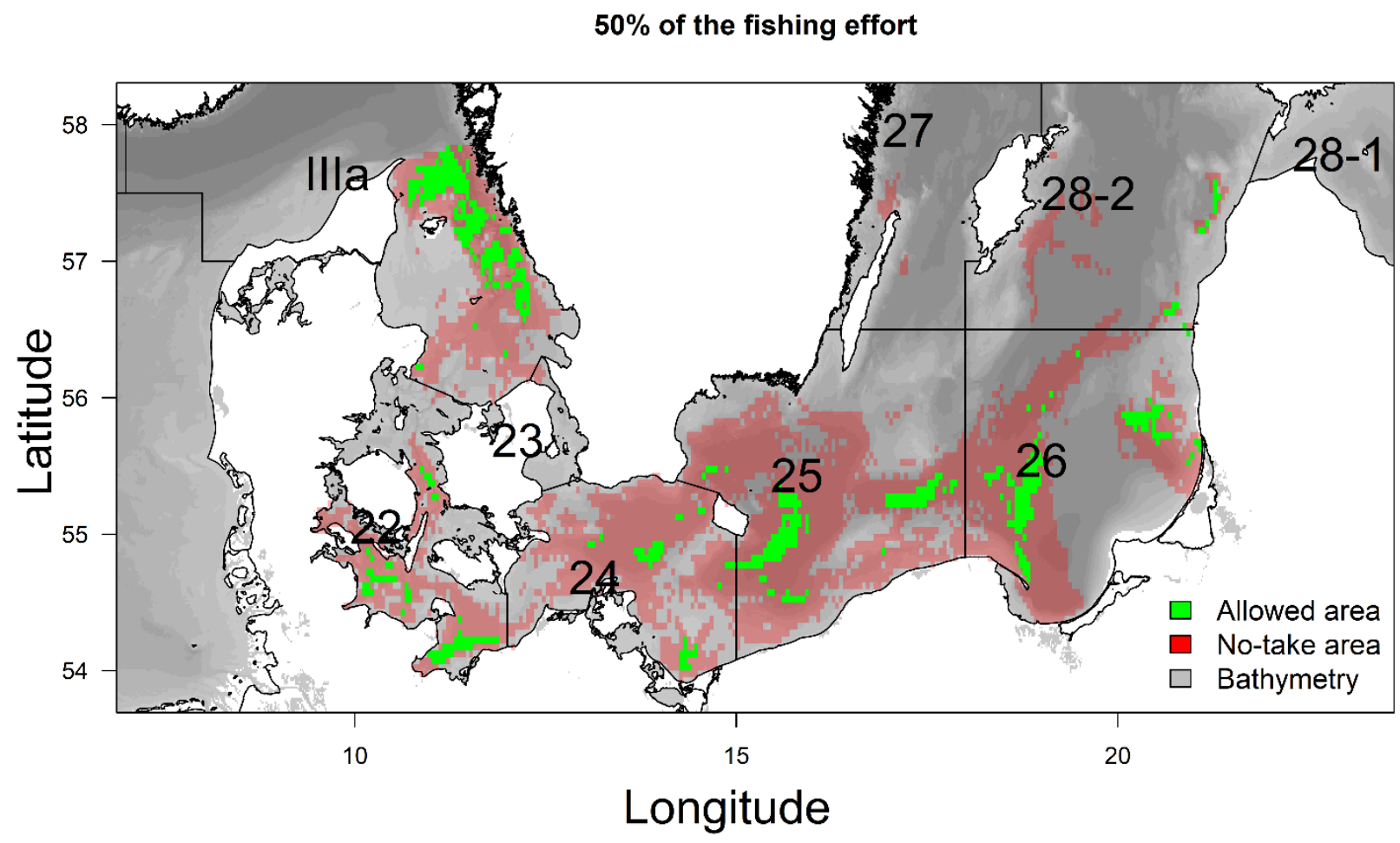

Figure 1. Corresponding surface area closed for bottom-contact gears when historical fishing spatial effort allocation is being cut starting from the peripheral cells towards the core cells of fishing grounds. The relationship is curved because the fishing tends to be patchily distributedly distributed by concentrating on some specific grounds, also showing that low effort occurred over a very large marine surface area (1\% of the effort explored ca. $20000 \mathrm{~km}^{2}$ of marine space). The allowed areas (in green) and no-take areas (in red) for bottom-contacting gears corresponding to a cut of 30\% or $50 \%$ in fishing effort starting from the peripheral fishing ground cells. In this illustration, the cut has been applied per Exclusive Economic Zone (EEZ) separately. Grey levels give the bathymetry extracted from gebco.net. The text labels correspond to the International Council for the Exploration of the Seas (ICES) for Baltic subdivision area naming (www.ices.dk). 

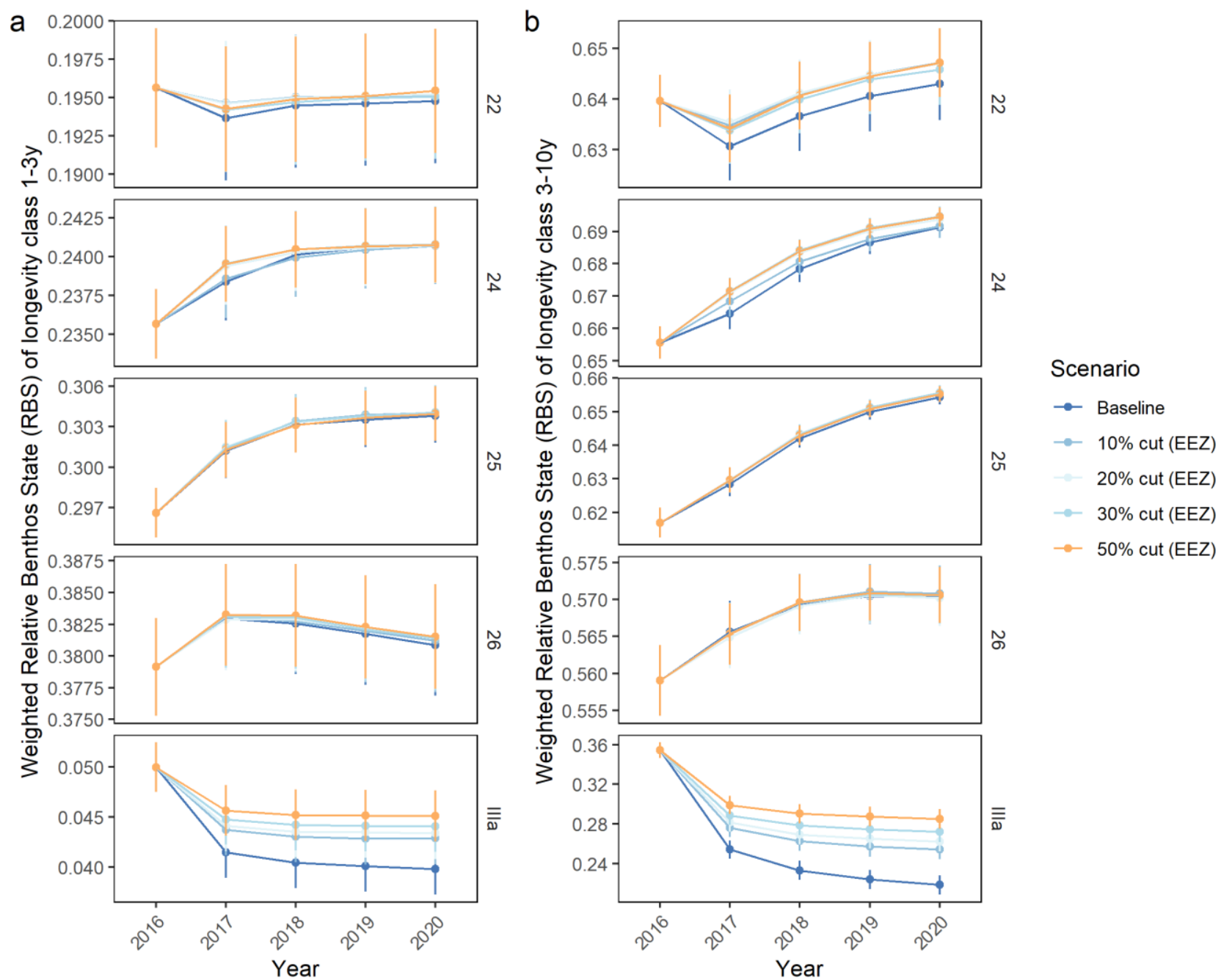

Figure 2. Evolution of the simulated relative benthos state for two longevity groupings a) longevity class 1-3 years, and b) class 3-10 years. The Relative Benthic Status RBS is standardised between 0 and the proportional value under undisturbed conditions from the initial state as estimated from an equilibrium state based on the fishing intensities in 2016, to the start of the fifth simulated year in DISPLACE, which are coloured per scenario and averaged over the International Council for the Exploration of the Seas (ICES) areas (22, 24, 25, 26, IIIa). Each solid line gives an average of 10 replicates per scenario, and the $95 \%$ CI is provided. The suite of tested scenarios contrasts with the baseline situation, in which no restriction applies, against a gradient of options given as a marine surface area percentage that is applied per national Exclusive Economic Zone (EEZ) for restricting access to bottom-contact fishing gears. The restricted area starts from the marginal cells, which are ordered from the lowest to highest fishing efforts observed to minimise the effect on the fisheries by displacing the least amount of effort. 

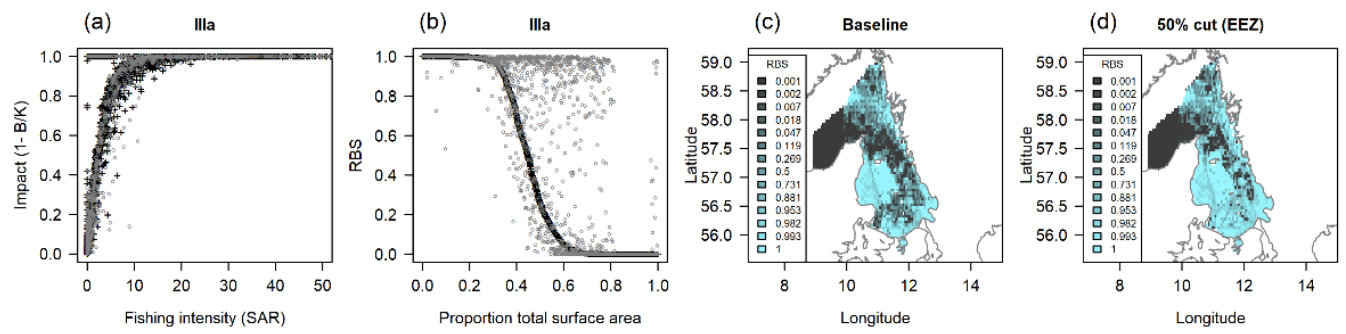

(e) 22
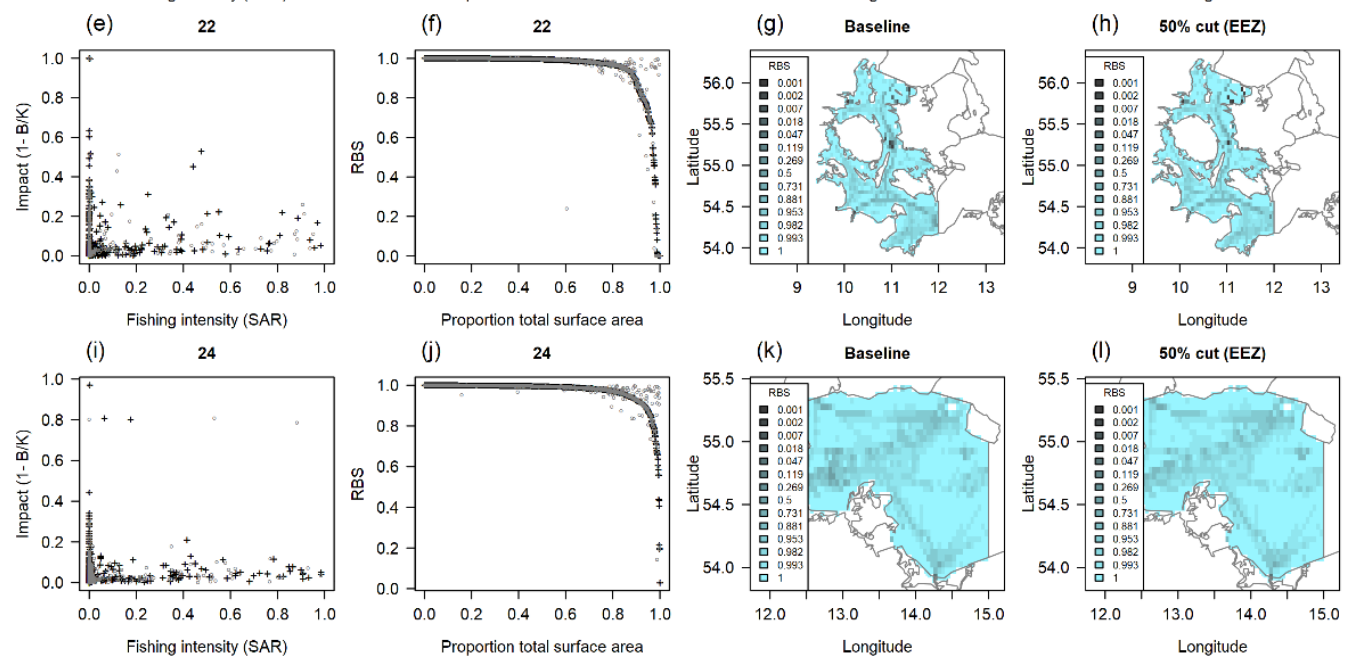

(m) $\quad 25$

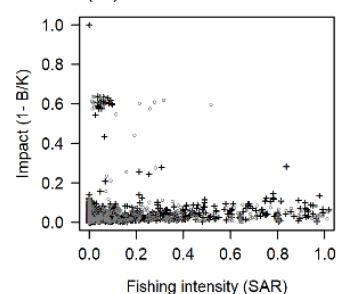

(n) $\quad 25$
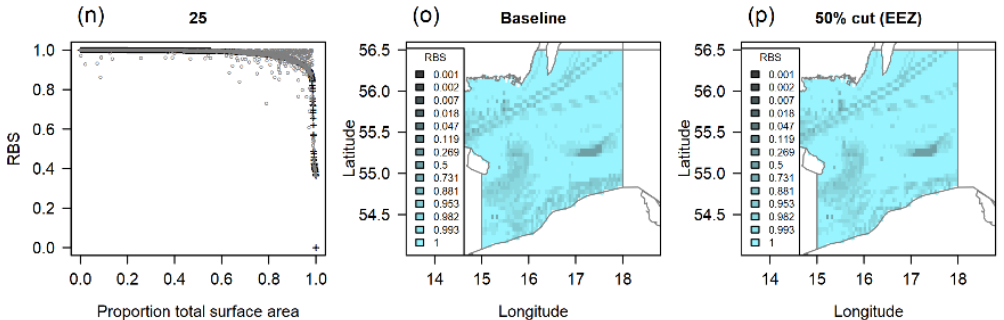

(q)
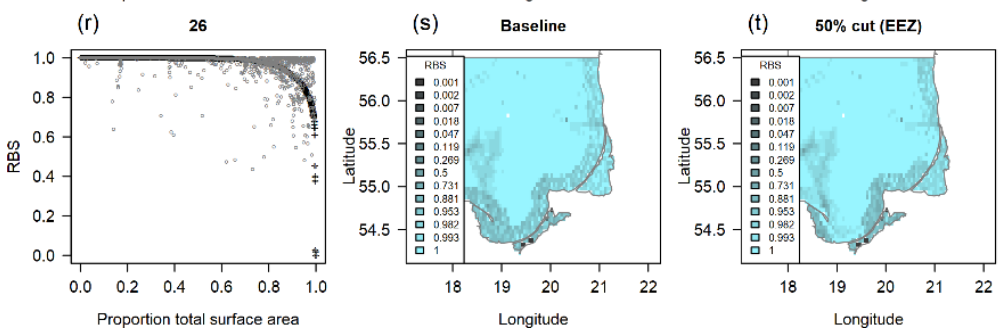

Figure 3. Relative Benthic Status (RBS) for the total community and per ICES area in the final simulated year for the baseline and one selected scenario, $a, e, i$, and $m$ : impact score (equivalent to 1-RBS) along with the increasing Swept Area Ratio (SAR); $b, f, j$, and $n$ : decreasing relative benthic status RBS and increasing proportion of total surface computed on the $x$-axis. The selected scenario is the one that applies a fishing peripheral cut of 50\% to fishing efforts and displaces these efforts starting from the peripheral low effort areas. The impact score or the RBS are given for the baseline (black points) and the scenario (grey points), and the scenario points are displayed with the same grid cell order as the one given by the baseline along the $x$-axis. The averaged RBS is weighted by the proportion of the biomass for each longevity group found in the grid cells. Graphics $c, d, g, h, k$, $l o$, and p: mapping the RBS in grid cells of 0.05 degrees. 
a
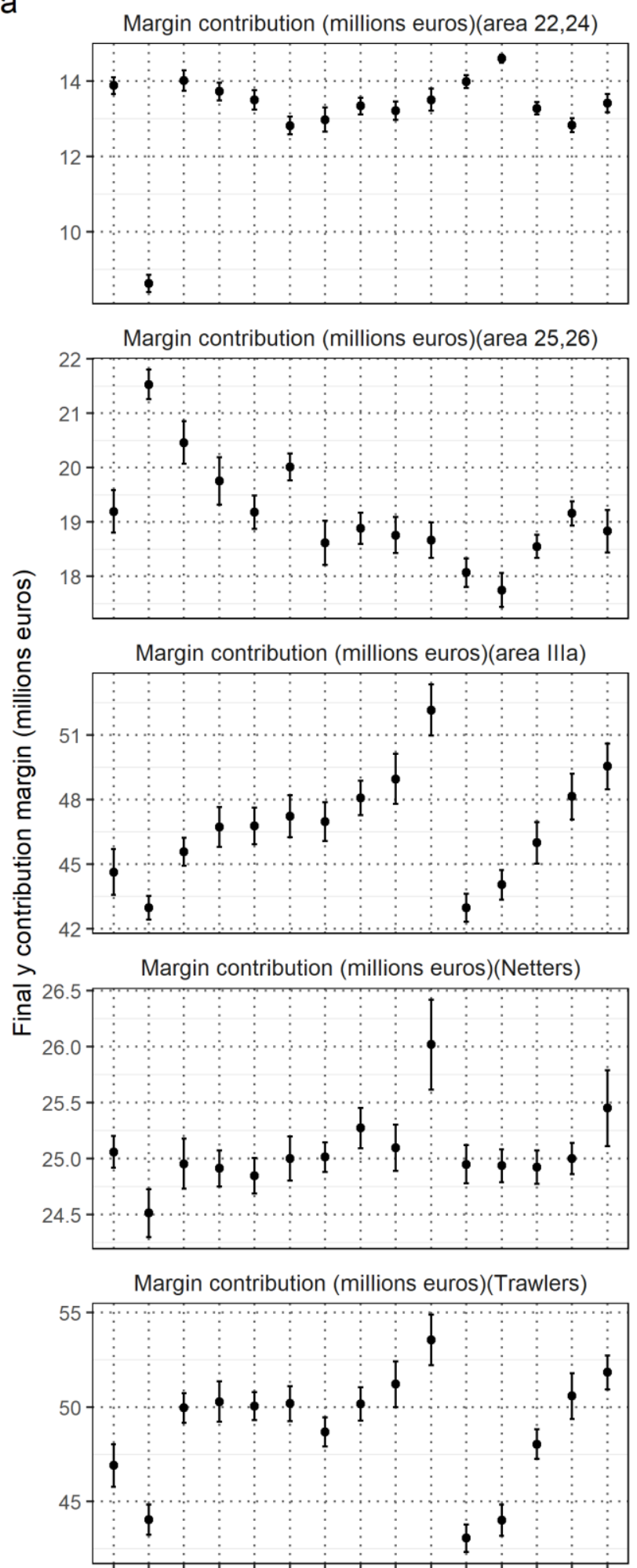

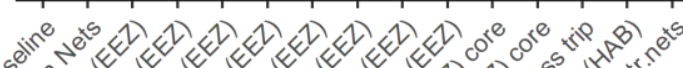

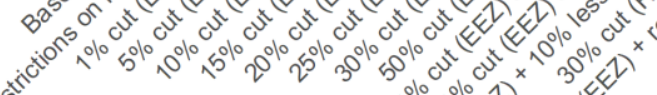

50

Scenario
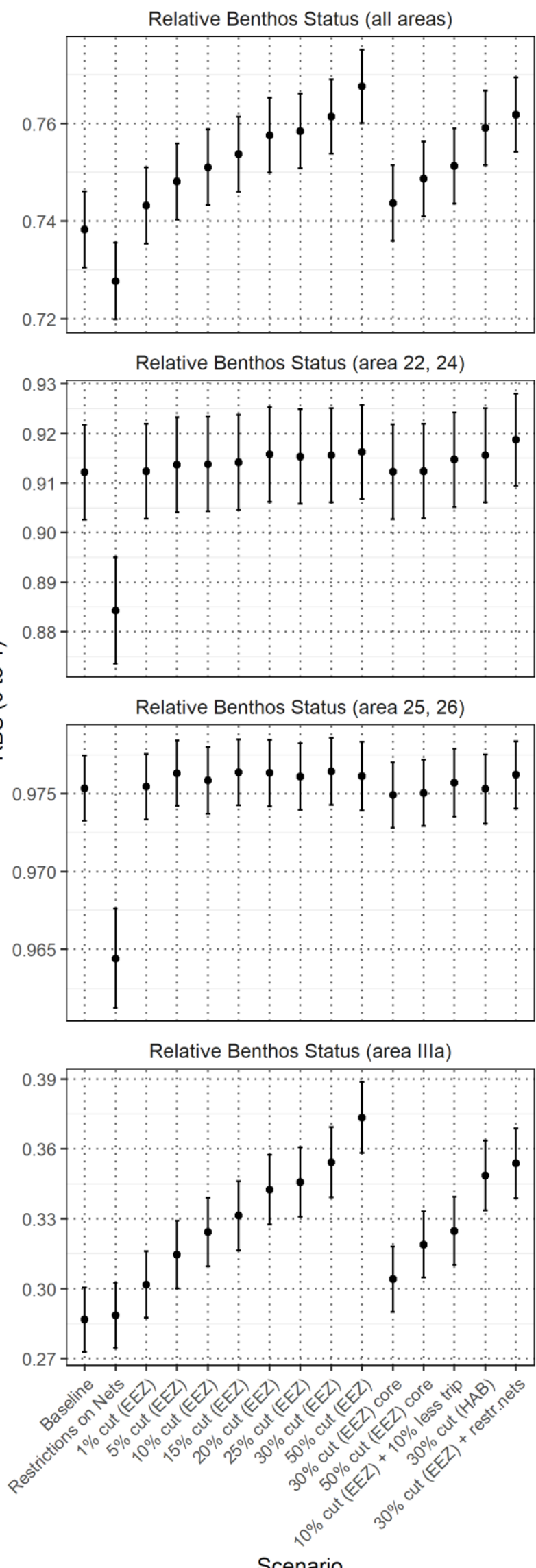

Scenario 
Figure 4. Last year of estimates with $95 \%$ confidence intervals at the 5-year horizon time of a-the simulated vessel contribution margins averaged per primary fishing area, and b-Relative Benthic Status (RBS) for the total community for selected scenarios and those averaged per ICES area. 
(a)

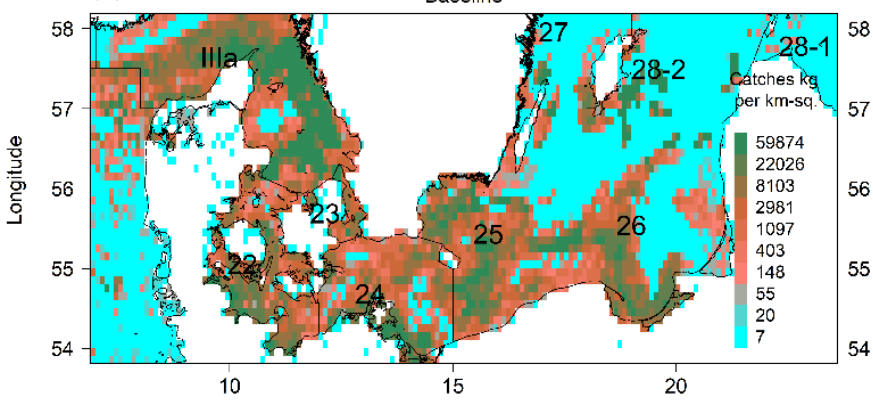

(b)

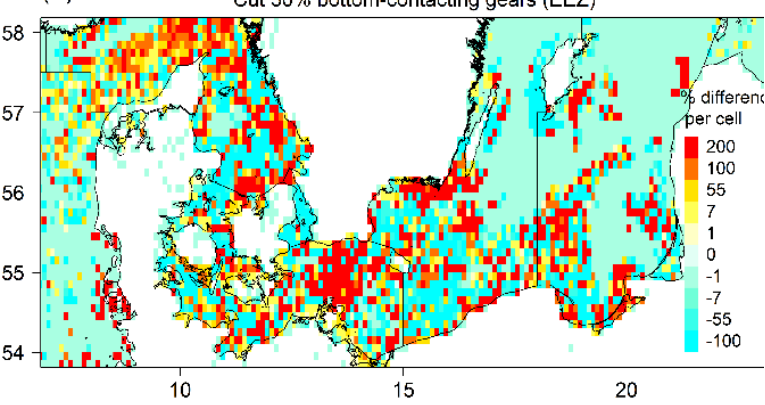

(c)

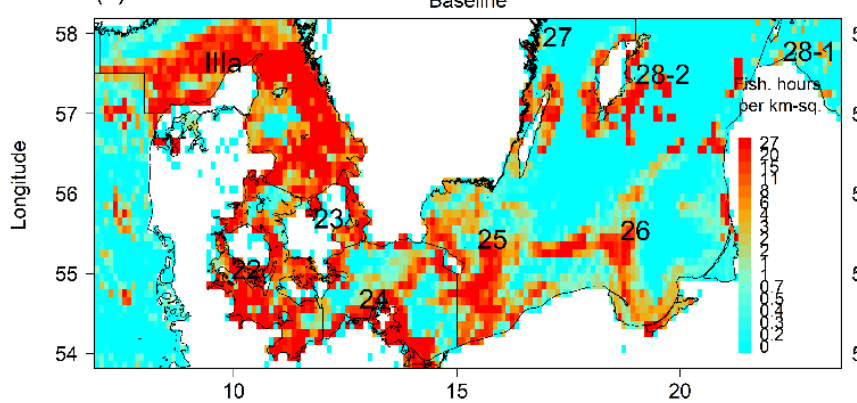

(d)

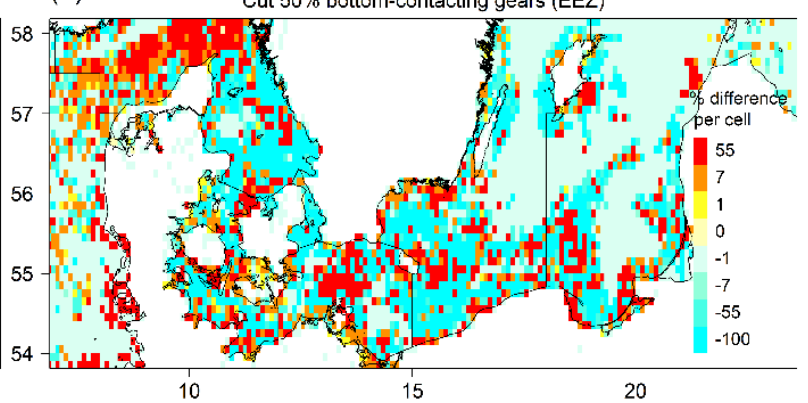

(e)

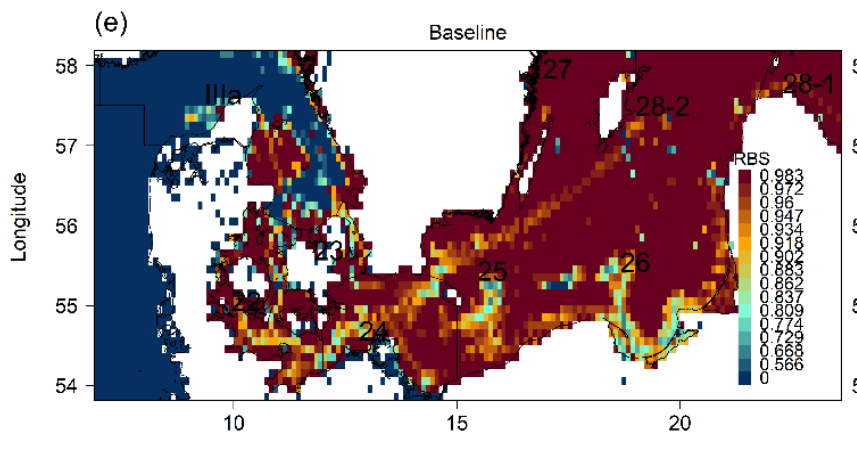

(f)

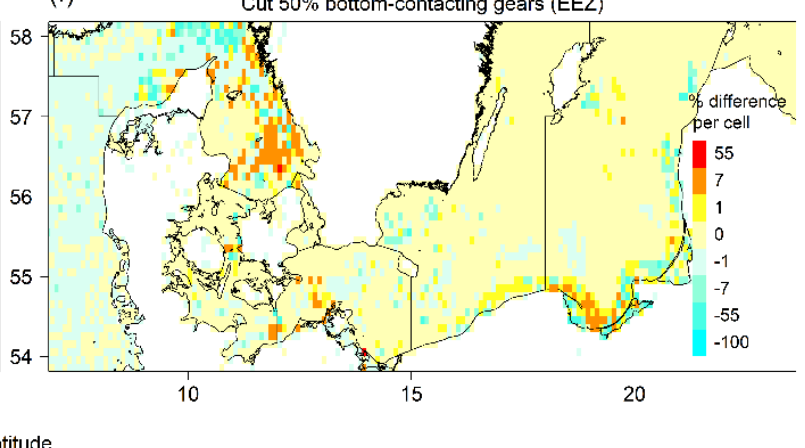

Figure 5. Spatial distribution of the simulated outcomes discretised on a grid of cells measuring 0.05 by 0.05 degrees (i.e., 0.05 c-squares) and integrated over the 5-year simulation period, for catches, the total of all landed species ( $a$ and $b$ ), fishing effort ( $c$ and $d$ ), and relative benthos status ( $e$ and $f$ ). The estimates are absolute for the baseline situation or given in percentages relative to the baseline for the 50\% peripheral fishing effort cut and displacing the bottom-contacting gears in the Exclusive Economic Zone, EEZ. 
Passive Gears

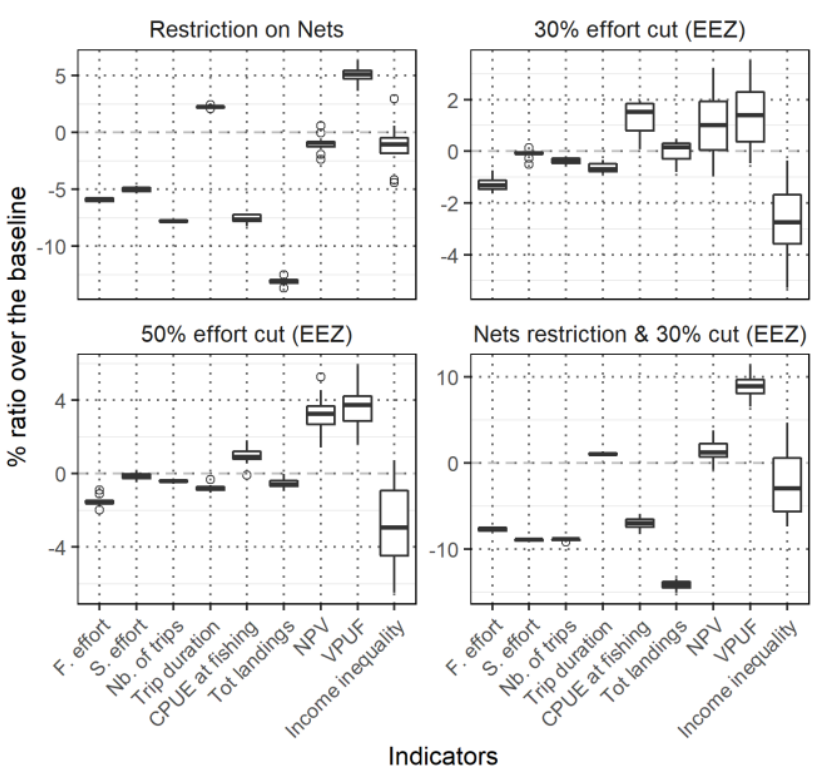

Bottom-Contacting Gears

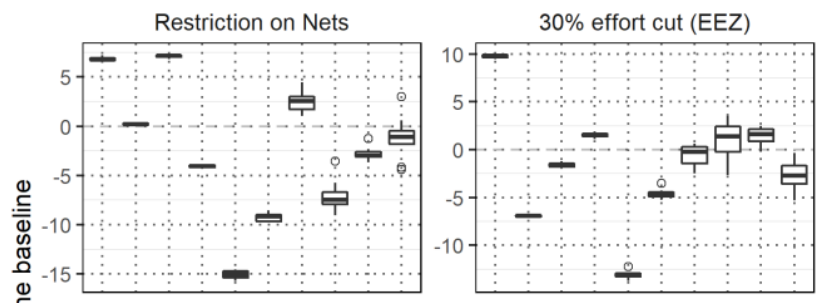

Nets restriction \& $30 \%$ cut (EEZ)

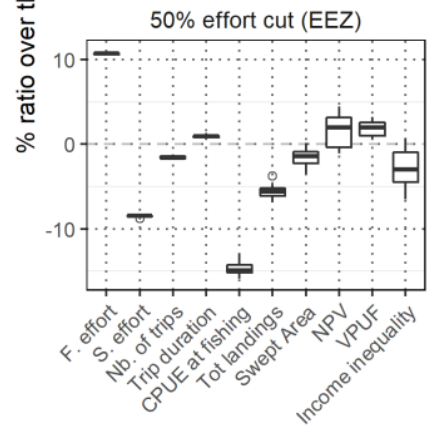

Indicators

Figure 6. Comparison of aggregated scenario outcomes (10 replicates per scenario) on the vessel performance indicators for vessels with passive gears (left panel) and towed gears (right panel) involved in the Baltic fisheries. The percentages are relative to the baseline condition for the fishing effort (F. effort), steaming effort (S. effort), number of trips ( $N b$. of trips), trip duration, catch per unit effort (CPUE at fishing), total landings for each considered stock (Tot land. Species), net present value (NPV) with a 4\% annual discount rate in Gross Value Added (GVA), value per unit fuel (VPUF), and income inequality computed based on the Hoover index. The baseline is given by the "focus on high-profit grounds" scenario, including the GoFishing and stopFishing decision trees designed to imitate the daily trip pattern (Supplementary Materials SM2). 

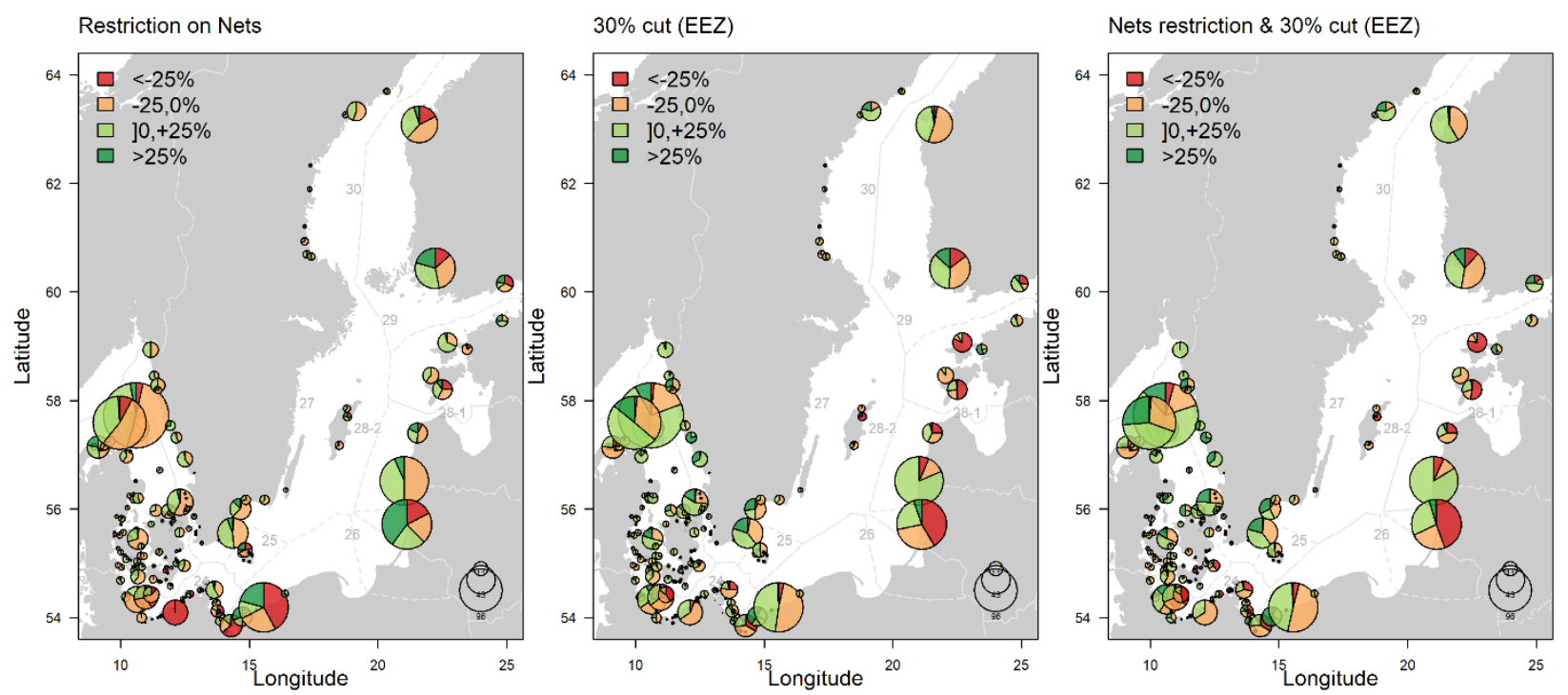

Figure 7. Stress level of fishing harbour communities at the 5-year horizon time for selected scenarios expressed as the proportion of simulated vessels with a change in income from landings that are classified into 4 categories ( $<-25 \%,-25-0 \%, 0-25 \%$, and $>25 \%)$ compared to the simulated baseline situation. The size of the circles gives the total landing income per harbour that accumulated over the 5-year period. 